\title{
‘Casual Classicism': In Conversation with Marc Quinn
}

\author{
Michael Squire ${ }^{1}$
}

Published online: 5 December 2017

(c) The Author(s) 2017

This article takes its lead from a recent set of sculptural works by the internationally renowned British artist, Marc Quinn: All About Love (2016-2017). The twelve statues in this series were displayed for the first time in a special installation at Sir John Soane's Museum in Lincoln's Inn Fields, London. Drawn from Life - the name given to the exhibition - ran for almost six months (28 March-23 September 2017): it received widespread attention not only on account of the works themselves, but also because of their installation amid the various rooms of Soane's Museum (e.g., Figs. 1, 2). ${ }^{1}$

Quinn's work must interest anyone concerned with the 'classical tradition'. ${ }^{2}$ Born in 1964, Quinn rose to prominence in the late 1980s and 1990s, as part of the socalled 'Young British Artist' movement (alongside the likes of Damien Hirst and Tracey Emin). After attending Millfield School (a private boarding-school in Somerset), Quinn studied history and the history of art at Robinson College (University of Cambridge), graduating in 1991. He then served as sculptural

\footnotetext{
${ }^{1}$ For the exhibition catalogue, see Marc Quinn: Drawn from Life, London, 2017 - the best photographic record, complete with a foreword by Bruce Boucher (Director of Sir John Soane's Museum), short essays by Alain de Botton and Daniel Leader, and an interview with Marc Quinn by Owen Hopkins.

${ }^{2}$ For a full list of Quinn's solo exhibitions, see the appendix at the end of this article, along with http:// marcquinn.com/exhibitions/solo-exhibitions. Solo shows have been held at, e.g., the Tate Gallery in London (1995), Kunstverein Hannover (1999), Fondazione Prada in Milan (2000), Tate Liverpool (2002), Irish Museum of Modern Art in Dublin (2004), Groniger Museum in Groningen (2006), Museo d'Arte Contemporanea in Rome (2006), DHC/ART Fondation pour l'art contemporain, Montréal (2007), Fondation Beyeler, Basel (2009), Fondazione Giorgio Cini in Venice (2013) and the Courtauld Institute of Art (2015). For a full list of accompanying catalogues, see https://shop.marcquinn.com/collections/booksand-exhibition-catalogues. The most important publication is Marc Quinn: Memory Box, Milan, 2013 accompanying the solo retrospective show at the Fondazione Giorgio Cini in Venice.
}

Michael Squire

michael.squire@kcl.ac.uk

$1 \quad$ King's College London, London, UK 




Fig. 1 Marc Quinn, All About Love 'Hot' (2016-2017), as displayed in the Monk's Parlour of Sir John Soane's Museum. Glass reinforced polyester and biresin polyurethane, stainless steel plate and rod, split shaft collars, softwood and far eastern ply; $213 \mathrm{~h} \times 64.5 \mathrm{w} \times 67.5 \mathrm{~d}(\mathrm{~cm})$. Reproduced courtesy of Marc Quinn, (c) Marc Quinn studio 




Fig. 2 Marc Quinn, All About Love 'Untrimmed' (2016-2017), detail, as displayed in the corridor of Sir John Soane's Museum. Glass reinforced polyester and biresin polyurethane, stainless steel plate and rod, split shaft collars, softwood and far eastern ply; $223 \mathrm{~h} \times 62 \mathrm{w} \times 67 \mathrm{~d}(\mathrm{~cm})$. Reproduced courtesy of Marc Quinn, (c) Marc Quinn studio

assistant to Barry Flanagan - under whom he learned many of the casting techniques that would define his future auvre. It was during the early 1990s that Quinn established his name in the British art world - above all, for his experiments with media: particularly famous is the series of portraits named Self (begun in 1991), made from the artist's own frozen blood (e.g., Fig. 3). ${ }^{3}$ Quinn's works have subsequently been acquired in collections across the globe, including the Tate (London), Metropolitan Museum of Art (New York), Peggy Guggenheim Collection (Venice), Stedelijk Museum (Amsterdam) and the Centre Pomipdou (Paris). A selected list of exhibited works is included as an appendix at the end of this article.

Quinn's sculptures, paintings and drawings have explored various themes - among them, mankind's relationship with nature, ideas and ideals of beauty, and the construction of modern social and cultural values. Throughout his career, though, the artist has also looked to classical antiquity as point of departure. His work has interrogated - above all through a sculptural medium - the legacy of Greek and Roman art, as well as its role in constructing the western aesthetic sensorium. With each intervention, Quinn invites viewers to look at ancient models anew, at once celebrating the aesthetic power of classical sculpture while interrogating its abiding cultural purchase. Perhaps more than any other living sculptor, Quinn has likewise turned to ancient models of visual representation to explore the 'modern': to challenge

\footnotetext{
3 On the development of the series, see especially the catalogue Marc Quinn: Selfs, Basel, $2009-$ accompanying an exhibition of four portraits at the Fondation Beyeler in Basel.
} 




Fig. 3 Marc Quinn, Self (1991). Blood (artist's), stainless steel, perspex and refrigeration equipment; $208 \mathrm{~h} \times 63 \mathrm{w} \times 63 \mathrm{~d}(\mathrm{~cm})$. Reproduced courtesy of Marc Quinn, (C) Marc Quinn studio

perceived binaries between nature and culture, for example, and to probe ideological distinctions between form and meaning, surface and depth, and body and mind.

The All About Love statues very much continue Quinn's fascination with the classical past. The statues are life-casts, and explore the artist's relationship with his partner, Jenny Bastet (cf. Fig. 6). But for all their careful attention to naturalistic detail, the statues are constructed as self-aware fragments, materializing a tension between the real and the manufactured, as indeed between past and present. ${ }^{4}$ The temporary installation in Sir John Soane's Museum was intrinsic to the thinking. This is not the first time Quinn has exhibited his work alongside ancient statues: in

\footnotetext{
${ }^{4}$ Themes of fragmentation have long come to the fore in Quinn's work - not least in his Complete Marbles (1999-2005), culminating in his portrait of Alison Lapper Pregnant (2004): cf. Figs. 17, 18, 19. Quinn's concurrent challenge to classical ideals and celebration of different bodily types have sparked particular interest in the field of disability studies: for extended discussion, cf. A. Millett, 'Sculpting Body Ideals: Alison Lapper Pregnant and the Public Display of Disability', Disability Studies Quarterly, 28, 2008 (available at http://dsq-sds.org/article/view/122/122); cf. A. Millett-Gallant, The Disabled Body in Contemporary Art, London, 2010, esp. pp. 57-63.
} 
2008, for example, his solid gold statue of Kate Moss (Siren) was installed at the entrance to the British Museum's Duveen Gallery; the back of the statue was turned away from the Parthenon marbles so as to gaze ahead at the crouching Lely Venus (Figs. 4, 5). ${ }^{5}$ The installation in Sir John Soane's Museum has a different effect. Once again, the juxtaposition throws a spotlight on the connections between antiquity and modernity. In this case, though, the encounter throws the very trope of fragmentation into relief. ${ }^{6}$

Rather than offer a survey or critical interpretation of Drawn from Life, the text that follows took advantage of the opportunity to chat informally with Marc Quinn about his recent work, and to ask him about his recourse to classical traditions more generally. My interest here forms part of a larger project on contemporary artistic responses to the art of the classical past, including a 2018 exhibition (that will incorporate Quinn's work) at King's College London. ${ }^{7}$ The project stems from a resurgence of interest in visual approaches to classical 'reception studies', 8 and a series of publications on the classical tradition in modern and contemporary art in particular. ${ }^{9}$ But it also seeks to initiate new sorts of conversation between scholars and artists. What is it about classical art that still so captivates the contemporary cultural imagination? How can contemporary responses help us to see classical art with new eyes? And what can such modern-day responses - situated against the backdrop of others, over a period of some two thousand years - tell us about current cultural preoccupations?

\footnotetext{
${ }^{5}$ On the Statuephilia exhibition at the British Museum (2008-2009), see http://www.britishmuseum.org/ about_us/news_and_press/press_releases/2008/statuephilia.aspx: the exhibition was intended to "encourage us to look afresh at both modern and ancient art - to explore the similarities as well as differences between eras and cultures, and to remind ourselves of the perennial power of sculpture.' For discussion of Quinn's sculpture here, cf. M. J. Squire, 'A Place for Art? Classical Archaeology and the Contexts of Art History', in Blackwell Companion to Classical Archaeology, ed. S. Alcock and R. Osborne, 2nd edn, Malden, MA, 2012, pp. 468-500 (468-71).

${ }^{6}$ More generally on fragmentation - and fragmentation as the signature-tune of the (post-)postmodern see in particular L. Nochlin, The Body in Pieces: The Fragment as a Metaphor of Modernity, London, 2001.

${ }^{7}$ For the project cf. www.modernclassicisms.com: the project is a collaboration with two post-doctoral researchers, Ruth Allen and James Cahill.

${ }^{8}$ For the key recent contribution, see E. Prettejohn, The Modernity of Ancient Sculpture: Greek Sculpture and Modern Art from Winckelmann to Picasso, London, 2012. For an overview of 'reception studies' in the field of classical art history - with detailed further bibliography, and some responses to Prettejohn's arguments - see M. J. Squire, 'Theories of Reception', in A Handbook of Greek and Roman Art and Architecture, ed. C. Marconi, Oxford, 2014, pp. 637-71; also relevant are a number of the chapters in the second volume of T. J. Smith and D. Plantzos (ed.), A Companion to Greek Art, Malden, MA, 2012.

9 Among numerous publications, cf. E. Cowling and J. Mundy, On Classic Ground: Picasso, Léger, de Chirico, and the New Classicism, 1910-1930, London, 1990; R. J. Barrow, 'From Praxiteles to de Chirico: Art and Reception', International Journal of the Classical Tradition, 11, 2005, pp. 344-68; K. E. Silver (ed.), Chaos \& Classicism: Art in France, Italy, and Germany, 1918-1936, New York, 2010; C. Green and J. Daehner (ed.), Modern Antiquity: Picasso, de Chirico, Léger, Picabia, Los Angeles, 2011; I. Loring Wallace and J. Hirsh (ed.), Contemporary Art and Classical Myth, Farnham, 2011; B. Holmes and K. Marta (ed.), Liquid Antiquity, Athens, 2017.
} 


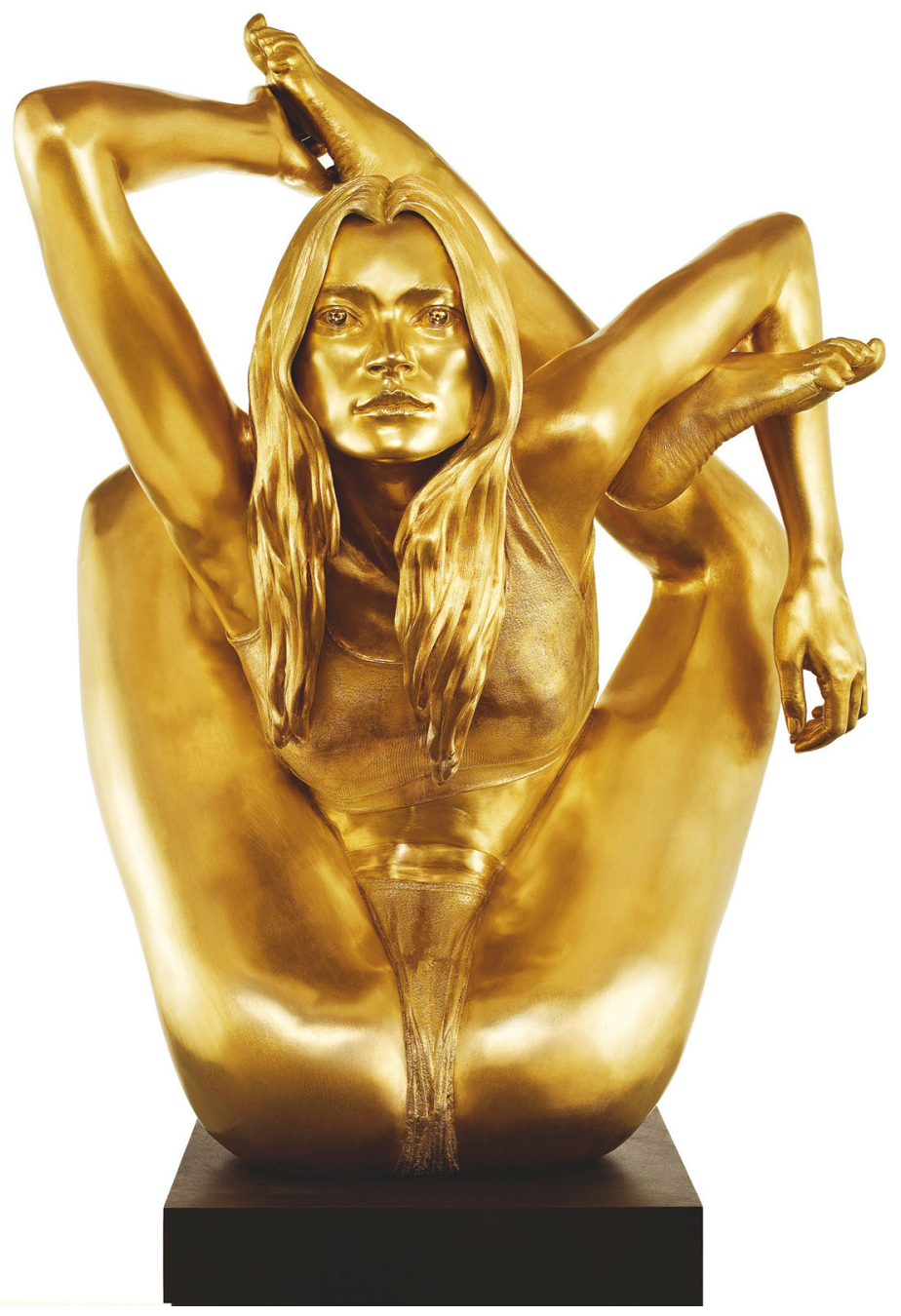

Fig. 4 Marc Quinn, Siren (2008). 18 ct. gold; 88 h $\times 65$ w $\times 50$ d (cm). Reproduced courtesy of Marc Quinn, (C) Marc Quinn studio 




Fig. 5 Installation of Siren (cf. Fig. 4) as part of the Statuephilia exhibition at the British Museum in 2008. Photograph by the author 
MS (Michael Squire): Marc, one of the aspects that has long defined your work is the knowing and reflective response to ancient Greek and Roman precedents. What is it about classical art that so intrigues you?

MQ (Marc Quinn): For me, classical sculpture is, in a way, the origin of figurative sculpture - it has given us the figurative sculptural language that we know. But what is interesting about classical sculpture is that it's really about the past, about time. Because so many of the sculptures are damaged - they're incomplete, with bits broken off them - they speak about a kind of loss. They make us think of a lost era - one that we can perhaps imagine as more perfect, better than the current... I think that's why people so like the idea of 'classical antiquity' too, because there's a kind of sense of a lost golden age, yet one somehow still with us.

MS: So the classical is about the past - but also the past in the present?

MQ: Yes, exactly. That's what makes it so rich.

MS: And 'classical' for you means - what exactly? Is it the sculpture of a particular time (the 'Classical' art - with capital ' $C$ ' - of the fifth and fourth centuries BC?)? A particular set of formal features - the 'naturalistic', the nude, a rendering of the body? Is it something defined by time - 'ancient' - or something more generic - does the 'classical' encompass the art of the Renaissance, for example?

MQ: No, it's something 'ancient.' But the 'classical' is also something broad, open to different definitions. Yes, it refers to Classical Greece - to a particular period within ancient history. But do you include Archaic sculpture too, or Roman art? The 'classical' is all antiquity, but still that's not really what the 'classical' actually is. It's an open and rich category.

MS: That 'openness' takes us to the Drawn from Life show, and to the twelve All About Love statues installed in Sir John Soane's Museum (Figs. 1, 2, 6, 7, 8, 9, 10, $11,12,13,14)$. I've heard you describe your work here as a kind of 'casual classicism'. ${ }^{10}$ What did you mean by that?

MQ: I think it's about how the classical is incorporated. Many of the sculptures in the show are based on particular poses from ancient statues: the arms of a Capitoline Venus, the frontal leg of a standing kouros, a pointing finger like the one from the colossal hand of Constantine in the Capitoline Museums (cf. Fig. 15).

${ }^{10}$ Cf. Marc Quinn: Drawn from Life (n. 1 above), p. 63. 


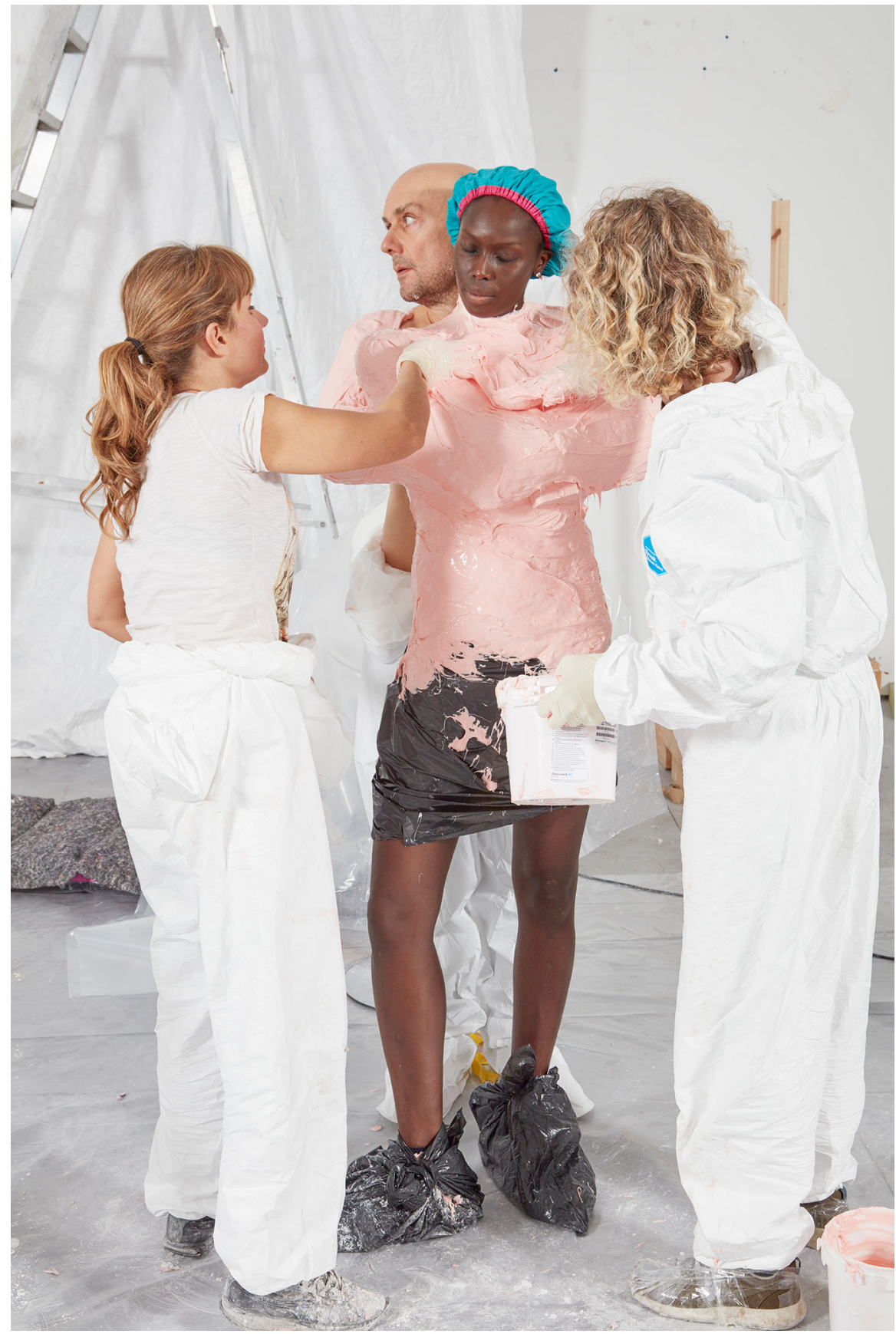

Fig. 6 Photograph demonstrating the production technique - the life-casting of Marc Quinn and Jenny Bastet for All About Love. Reproduced courtesy of Marc Quinn, (C) Marc Quinn studio 




Fig. 7 Marc Quinn, All About Love 'Eternal' (2016-2017), as displayed in the Breakfast Room of Sir John Soane's Museum. Glass reinforced polyester and biresin polyurethane, stainless steel plate and rod, split shaft collars, softwood and far eastern ply; $221 \mathrm{~h} \times 64 \mathrm{w} \times 45 \mathrm{~d}(\mathrm{~cm})$. Reproduced courtesy of Marc Quinn, (C) Marc Quinn studio 


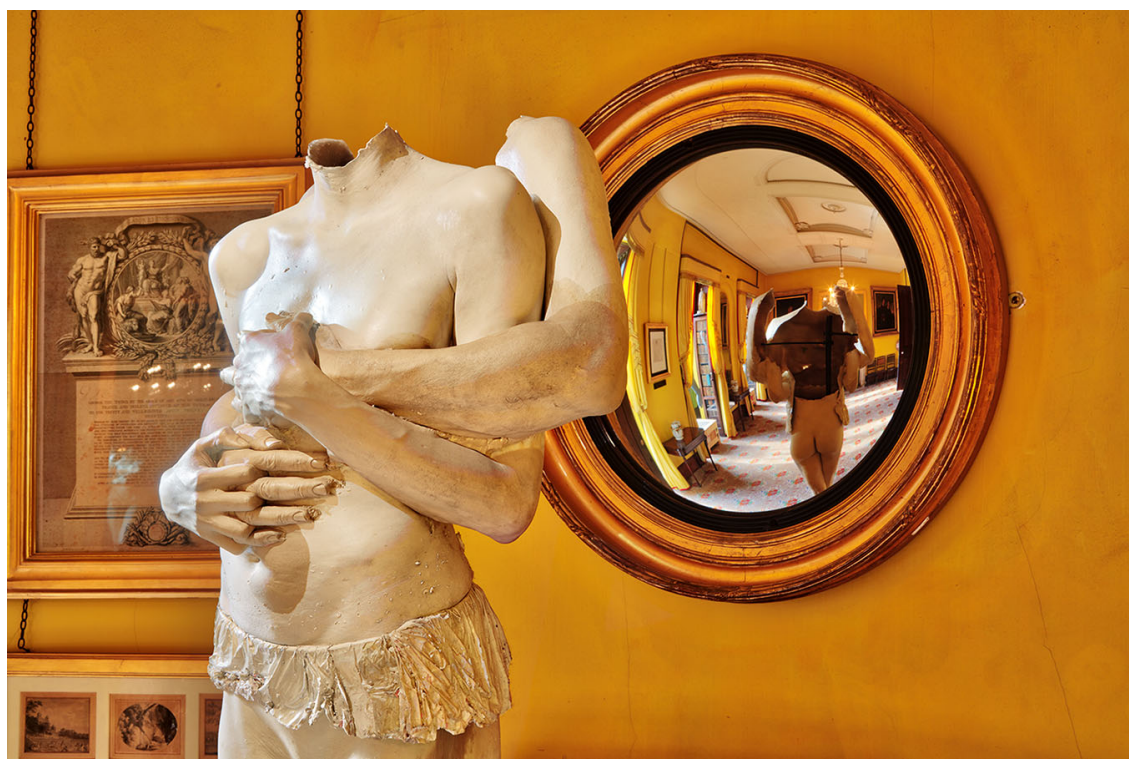

Fig. 8 Marc Quinn, All About Love 'Breathe' (2016-2017), as displayed in the South Drawing Room of Sir John Soane's Museum, with convex glass mirror behind. Glass reinforced polyester and biresin polyurethane, stainless steel plate and rod, split shaft collars, softwood and far eastern ply; $241 \mathrm{~h} \times 64 \mathrm{w} \times 63 \mathrm{~d}(\mathrm{~cm})$. Reproduced courtesy of Marc Quinn, (c) Marc Quinn studio



Fig. 9 Marc Quinn, All About Love 'Life' and 'Shines' (2016-2017), as displayed in the Library of Sir John Soane's Museum. Glass reinforced polyester and biresin polyurethane, stainless steel plate and rod, split shaft collars, softwood and far eastern ply; $219 \mathrm{~h} \times 62 \mathrm{w} \times 64 \mathrm{~d}, 213 \mathrm{~h} \times 56 \mathrm{w} \times 48 \mathrm{~d}(\mathrm{~cm})$. Reproduced courtesy of Marc Quinn, (C) Marc Quinn studio 
MS: And 'casual'?

MQ: Well, I mean, I know lots of these materials. Before making the statues, I looked through books on classical statuary. I'd forget about things. But then, when thinking about poses, soft versions of them emerged. So I guess that's what I meant with 'casual classicism': there are classical antecedents, classical debts, but in a very natural and naturalistic way. With a lightness of touch.

MS: Do you want to begin by describing the twelve statues?

MQ: The sculptures are made from fibreglass - but also made from life: they're life casts of myself and my Muse, Jenny Bastet. Each sculpture is cast in two parts, the first comprising the legs, the second the upper body. The legs are Jenny's alone. But with the torsos Jenny and I are holding each other in a certain way - always differently. So my arms, and only my arms, are in the sculpture, combined with Jenny's torso; as a result, the arms appear to be disembodied or floating, rather like the parts of a broken sculpture (where the body itself has been snapped off, and you're just left with the arms interacting with another sculpture). The combination creates a mystery - a kind of absence. The back of the sculpture is also left open. When we made the mould it only went round to the side of the torso because obviously we had to get out of it. So it's possible to look inside the sculpture from the back: you see how it's held up; you find this kind of abstract form in a way (cf. Fig. 11). The open back of the sculpture makes for a strange hollow shape: it's something abstract, almost like the unconscious of a sculpture. Each of the sculptures is mounted on a metal pole, placed on top of a wooden crate. In a way, the sculptures are about a relationship between two people: like an artwork, that relationship is a delicate thing, something that can be looked after, but something that can also be easily toppled or broken.

MS: So something precious and delicate - I've read you talk here of a 'frozen moment ${ }^{11}$ ?

MQ: Yes, 'precious', exactly. But also something immediate. I think a life cast is a very immediate way of making figurative sculpture. It's more like performance art in a way: you know, we have to stand in a certain position, the silicone rubber is put on top of us, and then we used plaster to keep the mould in shape. You end up with a mould from which you can make a sculpture that has a kind of reality and an unreality about it.

\section{MS: And then you had to get out of the mould - to escape?}

MQ: It's a laborious process. The non-toxic, silicon dental rubber is spread over the part of the body being cast, and then a plaster case is built around it - to make sure the shape is held when the rubber comes off. When the rubber is on, we're

11 Ibid., p. 63. 


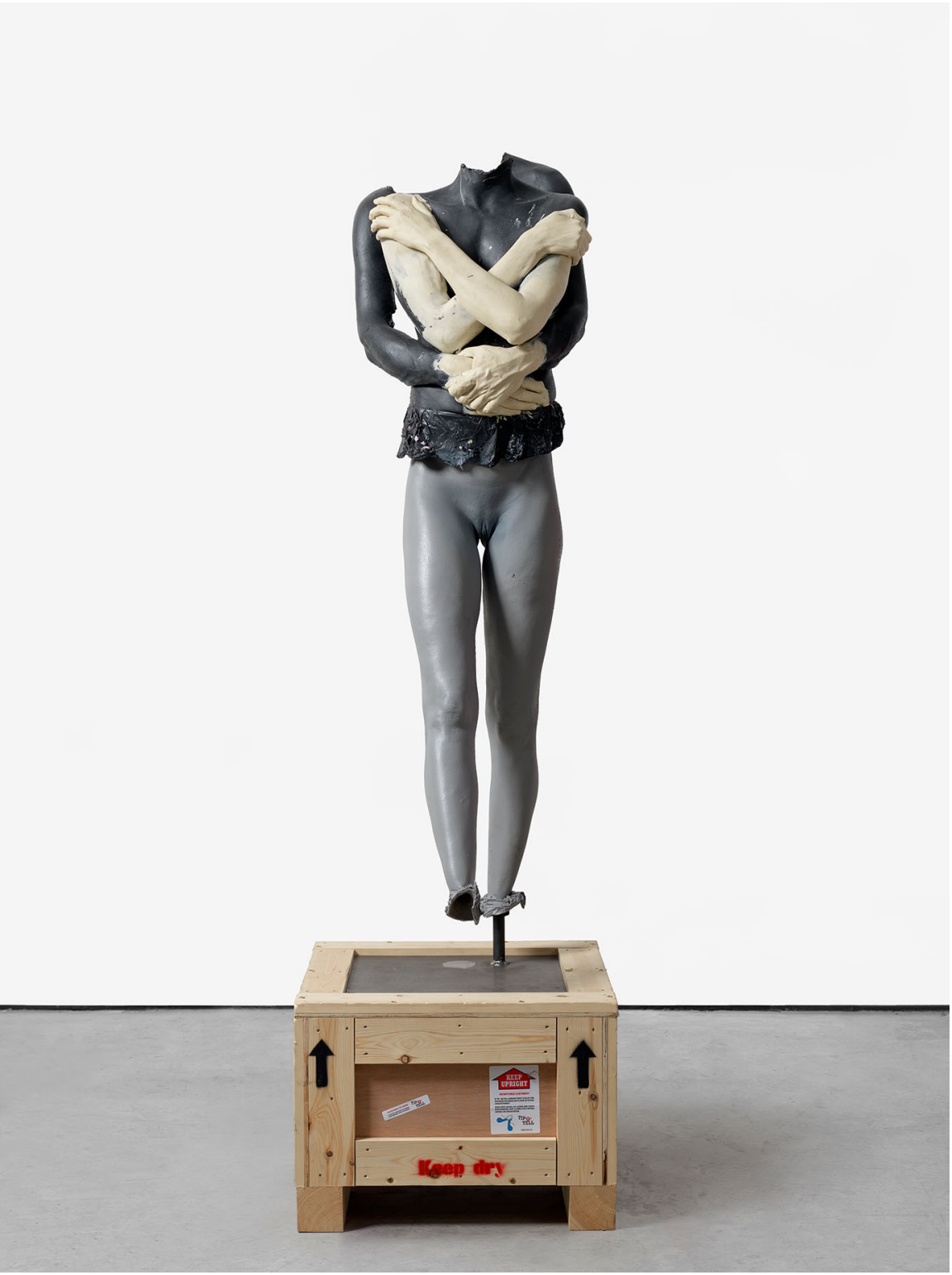

Fig. 10 Marc Quinn, All About Love 'Life' (2016-2017). Glass reinforced polyester and biresin polyurethane, stainless steel plate and rod, split shaft collars, softwood and far eastern ply; $219 \mathrm{~h} \times 62 \mathrm{w} \times 64 \mathrm{~d}(\mathrm{~cm})$. Reproduced courtesy of Marc Quinn, C) Marc Quinn studio

stuck together - like Siamese twins. The mould becomes very heavy, and we're bound together in this test of endurance. We'd support each other. But we'd also irritate each other. All of that somehow comes out in the statues. 


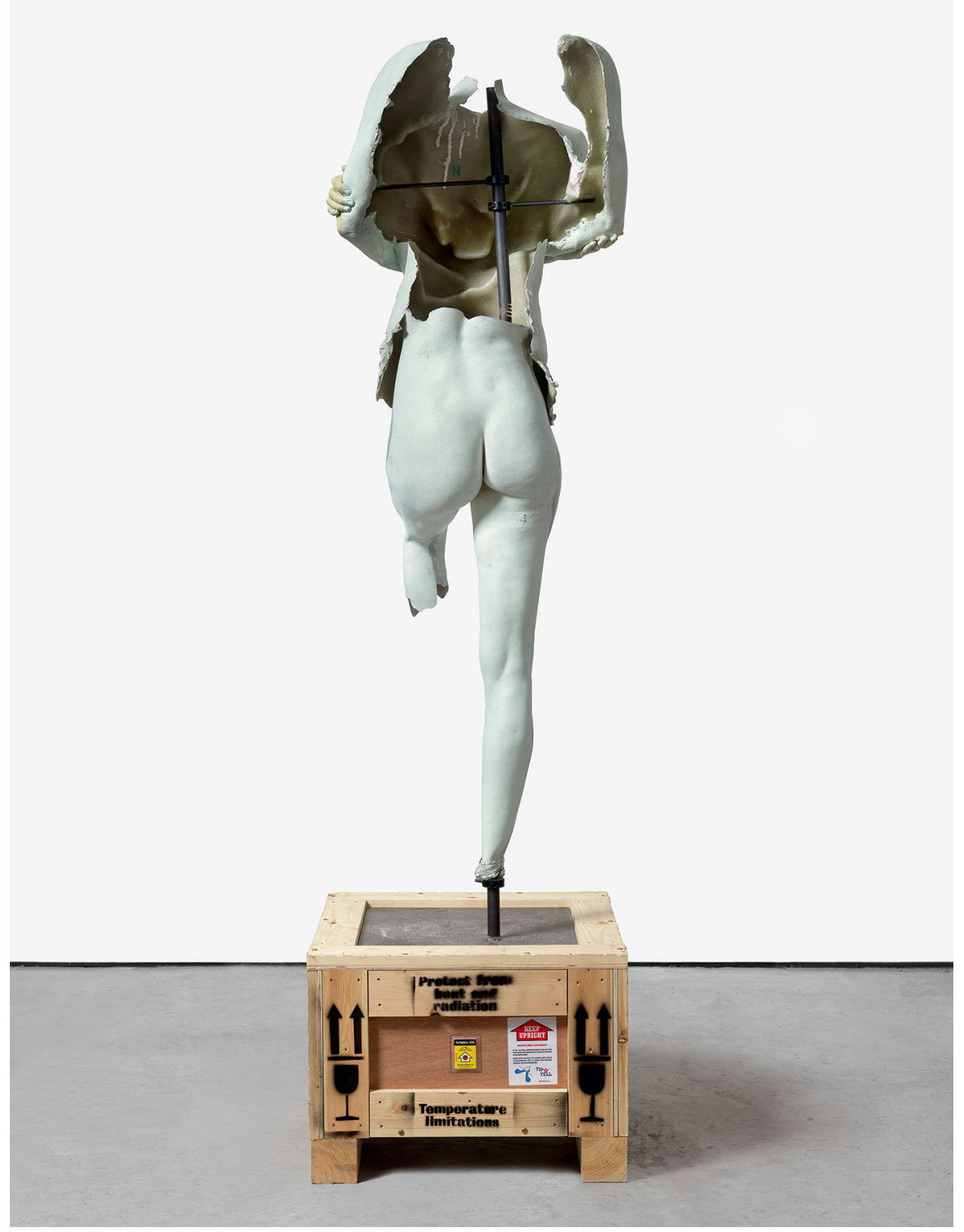

Fig. 11 Marc Quinn, All About Love 'Lovely' (2016-2017), as seen from the back. Glass reinforced polyester and biresin polyurethane, stainless steel plate and rod, split shaft collars, softwood and far eastern ply; $221 \mathrm{~h} \times 62 \mathrm{w} \times 68 \mathrm{~d}(\mathrm{~cm})$. Reproduced courtesy of Marc Quinn, (C) Marc Quinn studio

MS: In the exhibition you were keen to share the process of manufacture with your audience. One of the rooms upstairs shows one of those pink silicone moulds as part of the installation, accompanied by photographs of the casting process (cf. Fig. 6). The images in the catalogue frequently show your workshop team dressed in 


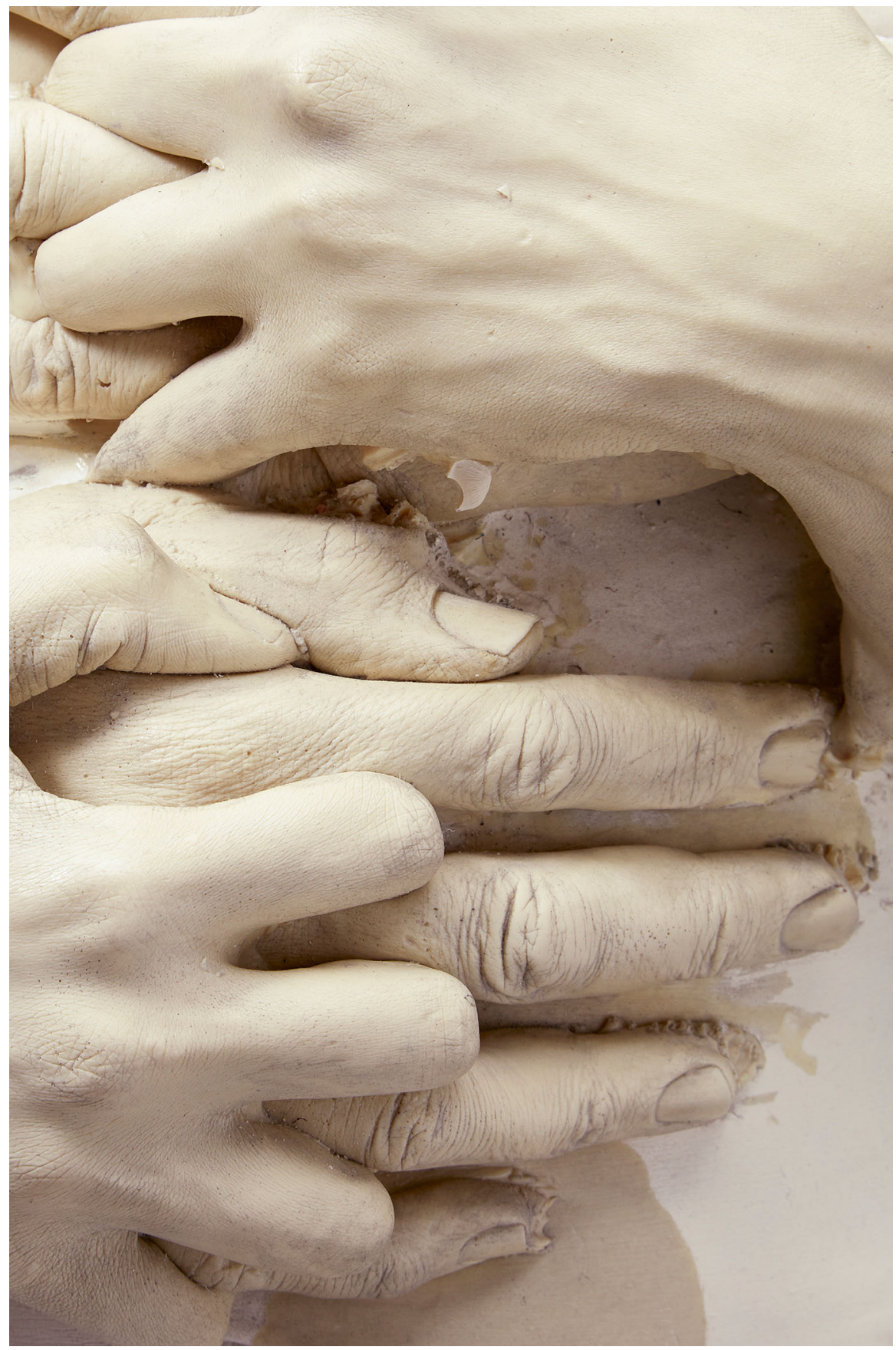

Fig. 12 Marc Quinn, All About Love 'Breathe' (2016-2017), detail. Glass reinforced polyester and biresin polyurethane, stainless steel plate and rod, split shaft collars, softwood and far eastern ply; $241 \mathrm{~h} \times 64 \mathrm{w} \times 63 \mathrm{~d}(\mathrm{~cm})$. Reproduced courtesy of Marc Quinn, (C) Marc Quinn studio 


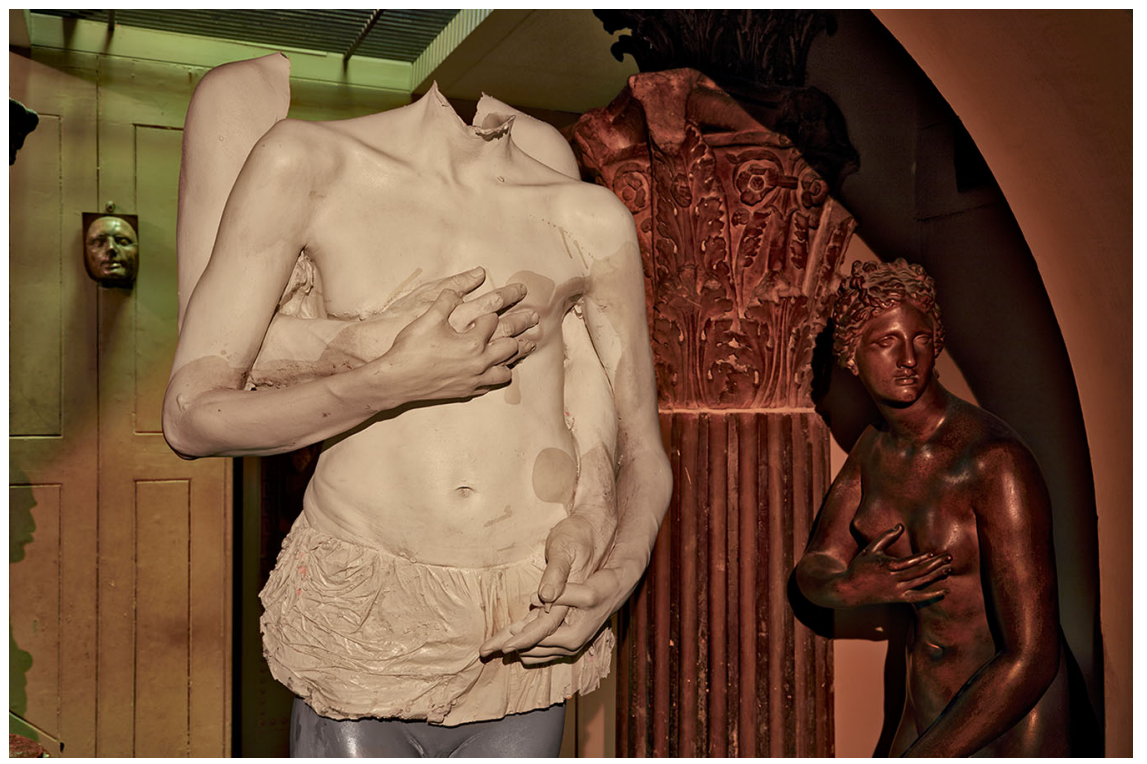

Fig. 13 Marc Quinn, All About Love 'Gold' (2016-2017), as displayed alongside a plaster cast of the Medici Venus in Sir John Soane's Museum. Glass reinforced polyester and biresin polyurethane, stainless steel plate and rod, split shaft collars, softwood and far eastern ply; $222 \times 69 \mathrm{w} \times 63 \mathrm{~d}(\mathrm{~cm})$. Reproduced courtesy of Marc Quinn, (c) Marc Quinn studio

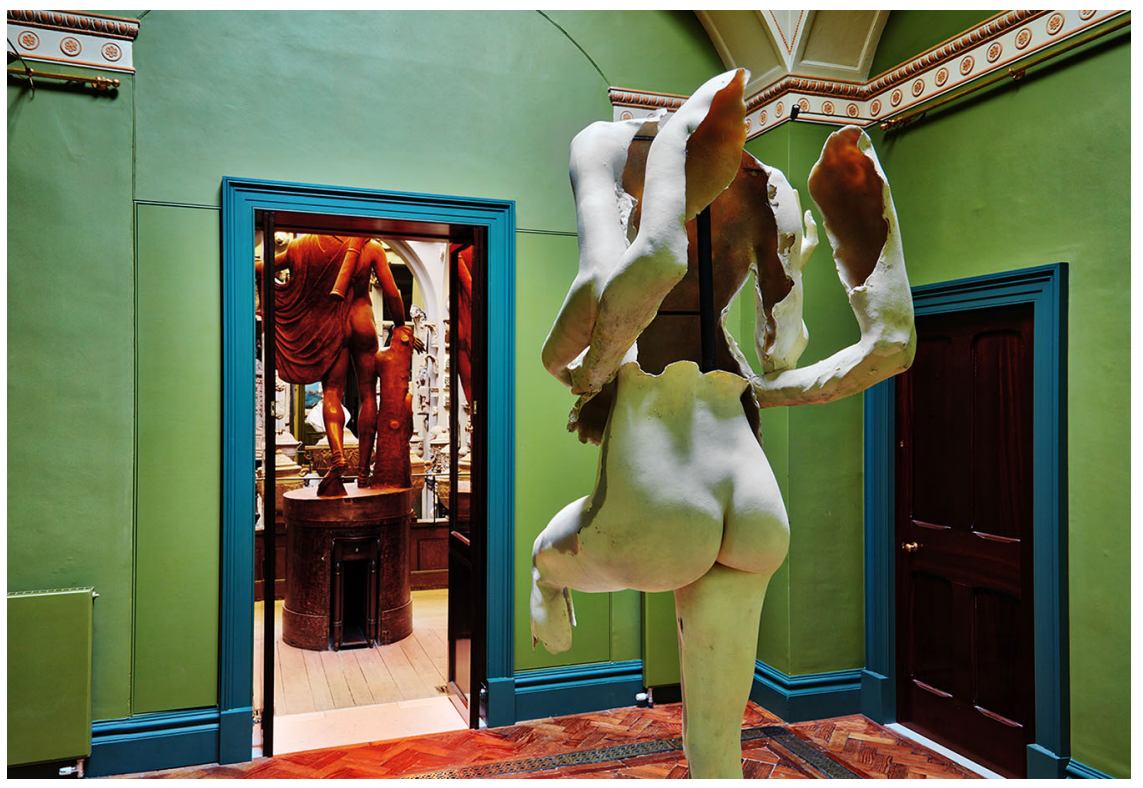

Fig. 14 Marc Quinn, All About Love 'Heaven' (2016-2017), as displayed in the Foyle Space of Sir John Soane's Museum, with a view out to a plaster cast of the Apollo Belvedere. Glass reinforced polyester and biresin polyurethane, stainless steel plate and rod, split shaft collars, softwood and far eastern ply; $214 \mathrm{~h} \times 66 \mathrm{w} \times 76 \mathrm{~d}(\mathrm{~cm})$. Reproduced courtesy of Marc Quinn, (C) Marc Quinn studio 
white coats - surrounded by tubs of gooey liquid silicon, potions, scalpels. ${ }^{12}$ It all seems very surgical - almost Frankenstein-esque, in a way.

MQ: There is something surgical, yes. The reality is that the statues are made using dental silicone for the moulds - you get incredible detail, like the pores of the skin, the hairs of a hand. But there's also an unreality about the result: the moulds move a little, they become slightly deformed as we escape from them. This gives the statues a baroque air - a little bit like wind is passing through them. The body itself is like drapery.

MS: And yet, perversely, this 'baroqueness' only adds to the eerie, naturalistic air of the works. When I was in the museum, in the Monk's Parlour (Fig. 1), I remember the arms of the statue named 'Hot' moving slightly when I walked around it - from the moving wooden floorboards....

MQ: Yes, exactly. The actual material used for the sculptures is a resin - two sorts, a runnier resin is first used for the hands; once that is dry a thicker fibreglass resin is placed on top. Once the resin is dried we have to break the plaster mould to remove it. The statues have these little 'skirts' on them too (cf. Figs. 1, 2, 7, 8, 9, 10, 13). It was a chance feature - something that happened as a result of the making process. Jenny tucked a bin-bag into her knickers - actually, to create a sort of plastic lining, something to stop the rubber dripping down onto her legs. In making the casts we included the first six inches or so of that lining as well. We thought about cutting this excess off. But then, when I saw it, I thought this is really interesting: it looks like a piece of drapery from a classical sculpture.

MS: It reminded me of the upper ridge of drapery on the 'Venus de Milo' (Fig. 16) - used to cover the join between the two blocks of stone. ${ }^{13}$

MQ: Yes, or a Dégas tutu.

MS: But here, unlike the 'Venus de Milo', both the upper and lower parts of each statue are naked.

MQ: And again there's a vulnerability. That 'dress', if you like, does not cover the pubic area: there's the vulnerability of her being completely naked.

MS: And we see the female genitals - something conspicuously absent in ancient images after the Knidian Aphrodite (sculpted by Praxiteles in the mid-fourth century $B C$ ).

MQ: 'Nakedness' seems to me important. There's a difference between the 'naked' and the 'nude': these sculptures are more naked than nude, I think.

\footnotetext{
12 Cf. Marc Quinn: Drawn from Life (n. 1 above), pp. 57-61, 64-7, 71-8.

13 Cf. A. Pasquier, La Vénus de Milo et les Aphrodites du Louvre, Paris, 1985, p. 24 - along with R. Kousser, 'Creating the Past: The Vénus de Milo and the Hellenistic Reception of Classical Greece', American Journal of Archaeology, 109, 2005, pp. 227-50 (with detailed further bibliography).
} 


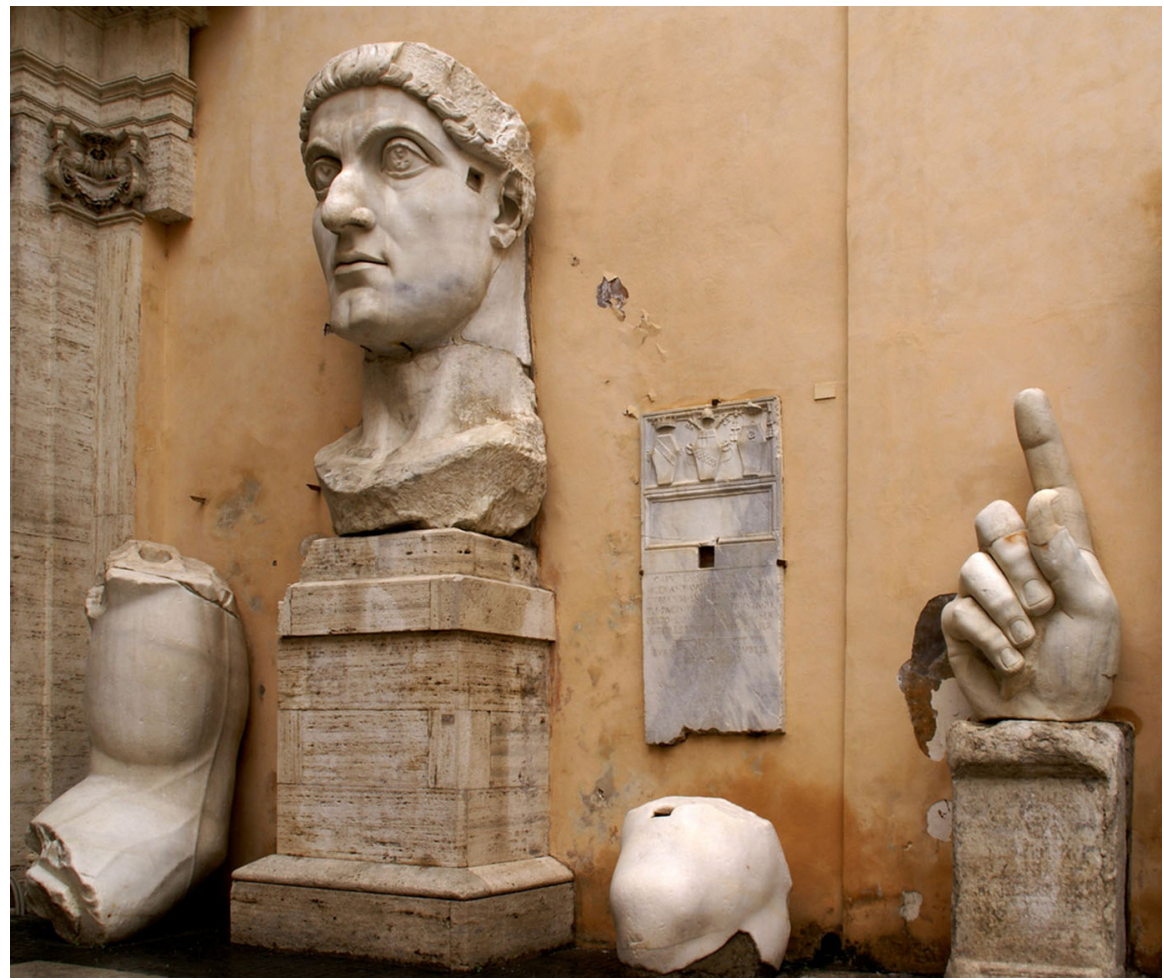

Fig. 15 Fragments of the fourth-century colossal acrolithic statue of the Emperor Constantine, as displayed in the courtyard of the Palazzo dei Conservatori in the Musei Capitolini at Rome. Photograph by the author

\section{MS: Exposed?}

MQ: Exposed. And, again, vulnerable. Emotionally, the result is something quite raw. But the rawness is also something technical. I didn't remove many of the faults - the problems that come from casting, and so on: I've left all of those features in there.

MS: So what is it about this tension between the 'naturalistic' and the 'nonnaturalistic' - between the 'believable' and 'true to life' on the one hand, and between the 'unreal' and 'baroque' on the other - that interests you? You go out of your way to capture anatomical details - hair, veins, goose-bumps (as on the buttocks of 'Heaven' [Fig. 14]). ${ }^{14}$ But you also puncture the illusion - through the ungrounded appearance of the statues, their missing feet and fragmented limbs, the revelation of sculptural form as hollow 'skin', the visible steel supports....

${ }^{14}$ Cf. Marc Quinn: Drawn from Life (n. 1 above), p. 63: 'What's interesting is that the rubber is very soft, but it's also very strong and, for instance, it pulls all the hairs out my arm so when we cast the resin, the resin arm acquires my hair and the sculpture ends up with real hair in it. There is this transference of some of the surface details of life into the sculpture.' 


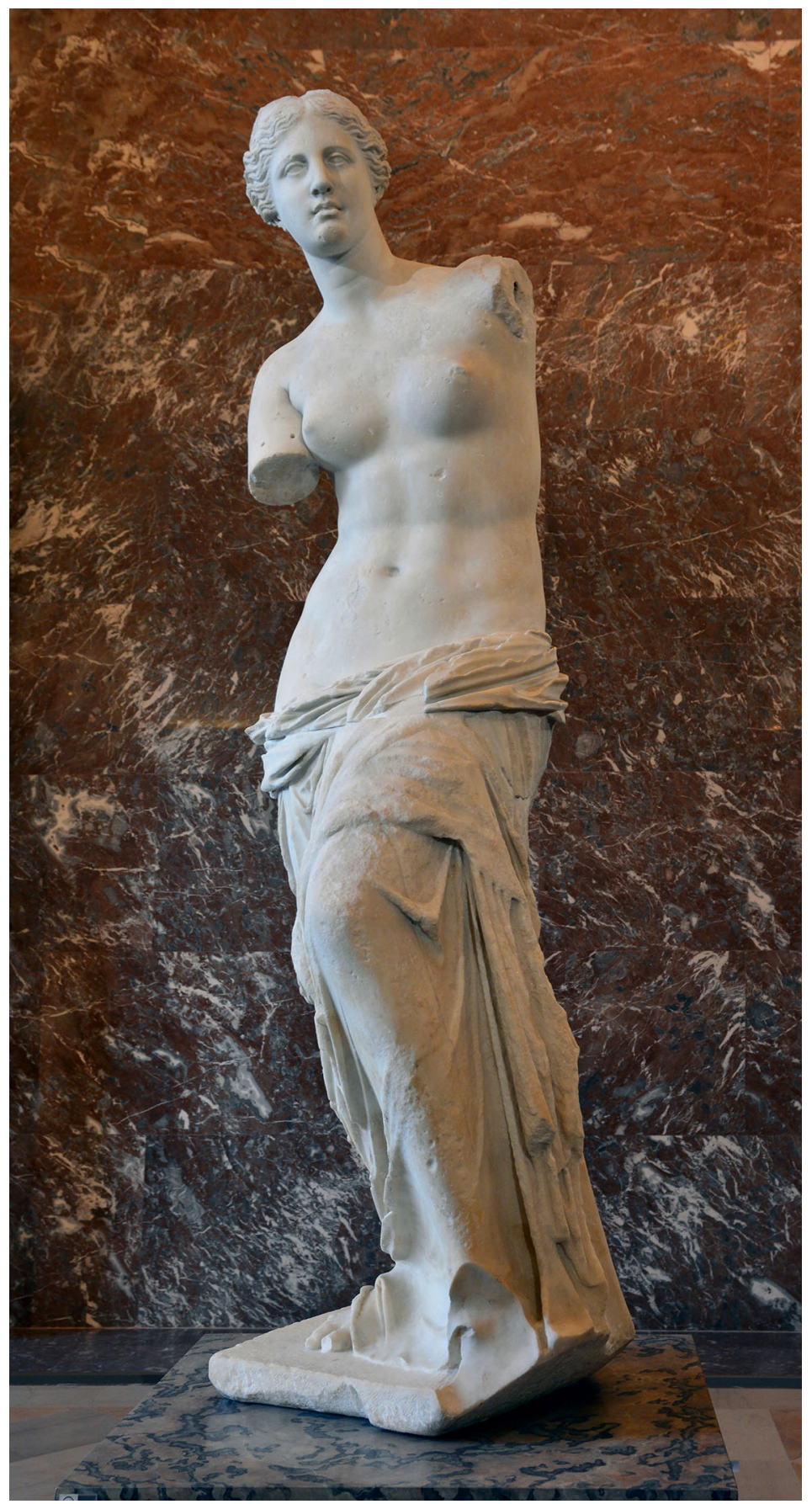

Fig. 16 Hellenistic 'Venus de Milo' statue, as displayed in the Musée du Louvre in Paris; marble, 202 h (cm). Photograph by the author 
MQ: Well, I think if you have sufficient 'believable' prompts - signposts, almost - then you just accept everything as real. Take 'Heaven' - displayed in the Foyle Space, directly behind Soane's large cast of the Belvedere Apollo (Fig. 14). When you are in the Foyle Space, and you look past my sculpture to the Belvedere Apollo, suddenly that statue - which had seemed so realistic - looks completely abstract, idealized, simplified, not like a real body at all. That's the thing: our view of the Apollo changes besides the life cast, because a life cast is not an ideal. It's a kind of reality - much more suited to our age than the ideal, I think.

MS: So it's the juxtaposition between the two that's important?

MQ: By having the two next to each other, you really do see the difference.

MS: The tension between the real and the unreal goes hand in hand with the ambiguity of the different poses. Is this wavering of gesture - between holding and supporting on the one hand, and fighting or restraining on the other - something intentional?

MQ: Ambiguity is almost more interesting than resolution, I think. It's the same reason we like fragments: they are an ambiguous thing; they preserves a mystery. We can fill in the blanks for ourselves. That's why it was important that these sculptures don't have heads either: if they had heads, then we'd interact with them differently you'd just spend the whole time looking at the face. The fact that there's no head makes each statue more universal - I wanted to put the expression in the hands.

MS: Interesting - those comments makes me think about your own portraits in the Self series, to which we'll come back later. But, sticking with All About Love, let me ask about the hands: these are of course the parts that ancient sculpture most often lacks. Arms are missing, and hands are broken off. But in your statues the hands come in for the most detailed sort of anatomical attention (e.g., Figs. 2, 12).

MQ: I think it's probably an unconscious thing, a reversal of the normal situation. The feet are gone. The whole of my body is gone. The head is gone. Yet the hands remain.

MS: And the sense of tactility - the gesture of embrace - is brought to the fore. Is there something programmatic at work here? I'm thinking about the difficulty western artists have always with feet and hands - not least in the Renaissance. But I'm also thinking about classical sculpture's 'haptic' appeal - something we all too easily forget within the museum. Until last year, the Lely 'Crouching Venus' in the British Museum - against which you juxtaposed your Siren sculpture in 2008 (Fig. 5) - was displayed next to a sign saying 'Please do not touch!.'

MQ: Absolutely. One of the things I like about fibreglass - the medium in which these sculptures are cast - is its feel. It's a very contemporary material, usually 
associated with car body shops and the like. It's incredibly strong. And yet, when you touch it, it has this kind of egg-shelly quality: even though it's incredibly strong, the statues feel very delicate.

MS: Which brings me back to those boxes on which the statues are installed: these are no standard 'plinths', but instead everyday plywood crates, complete with labels like 'Keep upright', 'Fragile', 'Keep away from heat.'

MQ: Yes, they are transport crates - functional things used to move artworks. As I said earlier, the sculptures are about a relationship between two people, and like an artwork that relationship has a fragility about it. But what's in the crates? Obviously they can't fit the sculptures inside....

MS: So what is inside the crates?

MQ: I don't know. Nobody knows. As I say, it's almost like the unconscious of the sculpture - or something like that.

MS: I sense it's the delicacy of these various 'relationships' that's important to you. The relationship with antiquity. The relationship with sculptural form. The relationship with Jenny (after all, they're All About Love). Given what you just said earlier about 'universals', why did you decide to insert yourselves - you and Jenny - into the sculptures?

MQ: I think it's about 'adding' - infusing them with real life, with a true story. But the works are also about making something concrete. If I'm in a loving relationship with someone, and I make sculptures about that relationship, I thought that there would be more reality in the statues if they are based on $u s$ as opposed to two random people. It's almost like a superstitious thing. If you love somebody, the work becomes a monument to that relationship in some way: whatever happens in the future, it preserves something beautiful, something universal, something eternal. I don't think audiences need to know anything about the specific story of our relationship. But I am saying that if two people are in a relationship they will instinctively hold each other differently than two actors or models.

MS: That takes us also to the issue of the series. We are talking here not just about one statue, but twelve. How important is the repetition and variation from one sculpture to the next?

MQ: I couldn't do what I wanted to do in one statue. I felt there was more to say - and different poses to try out. When we got to twelve, I thought that was perhaps now enough. I mean, I could have gone on forever. But it's quite nice just to stop at a certain point. And I think that they are all different from each other. There's no repetition, and each is unique. 
MS: And yet they fit together - in terms of their form, production methods and juxtaposed display. I' $m$ wondering here about your take on the 'formula': of course, the whole history of classical art is about adopting and adapting motifs, schemata, positions....

MQ: Classical art is much more commercial than people think - and I don't mean necessarily commercial just in the sense that people bought it. Once you had a great version of something, there seems to have been a market for it. It was wanted for different temples, different palaces, different towns, different cities. The ancient world was much less connected than ours - it was without internet, for one thing. Unless you go from Asia Minor to North Africa, you're not going to see the same statues in your town square. I'm thinking about the Prada show two years ago, with its statues of the same subject from all over the world. Don't you think there was a much greater sense of these things being sent out - almost like sculpture factories?

MS: In some ways - and we do have some evidence of making plaster 'casts' of statues in the Roman world. ${ }^{15}$

MQ: Yes, but I'm also thinking much earlier. Even in the Archaic Greek world some 500 years earlier.

MS: We've spoken quite a lot about antiquity, so let me move forward in time. It would of course have been possible to give these statues ancient names. But you instead opted to give each sculpture a one-word title taken from Shakespeare's sonnet 'Shall I compare thee to a summer's day?'. ${ }^{16}$

MQ: Yes. And I then just chose as titles words that wouldn't sound like they came from that poem. A sort of hidden reference.

MS: Re-reading Shakespeare's poem, I was struck by the final couplet of the sonnet, 'so long as men can breathe or eyes can see, so long lives this and this gives life to thee.' Was that important to you?

MQ: Yes, that too. You take something that's fleeting and delicate - something that is potentially ephemeral, like a relationship - and then you make it last forever....

MS: The idea of 'giving life' also made me think of the famous myth of Pygmalion - the story of the sculptor who made his statue, falls in love with it, and

\footnotetext{
${ }^{15}$ For an introduction (focused on terminology), see A. Anguissola, 'Difficillima imitatio': immagine e lessico delle copie tra Grecia e Roma, Rome, 2012, pp. 179-83; cf. R. Frederiksen and R. Marchand (ed.), Plaster Casts: Making, Collecting and Displaying from Classical Antiquity to the Present, Berlin, 2010. For the most detailed overview, see now A. Reinhardt, 'Reproduktion und Bild: Zur Wiederholung und Vervielfältigung von Reliefbildern und -objekten in römischer Zeit', Unpublished PhD dissertation, Humboldt-Universität zu Berlin, 2015, pp. 20-94 (with catalogue at pp. 324-51).
}

${ }^{16}$ Cf. Marc Quinn: Drawn from Life (n. 1 above), p. 97. 
longs for the statue to come to life. ${ }^{17}$ In Ovid's version we hear how Venus fulfills Pygmalion's prayer - the statue comes to life beneath the artist's 'probing finger'; she is touched, and she touches in turn... Did the myth form part of your thinking?

MQ: Not deliberately. I mean, yes, obviously there is something about bringing an artwork to life at work. But in fact my model is already alive - she is living to begin with.

MS: So 'casual classicism' again?

MQ: And 'reversing.' These works are as much about freezing something as they are about bringing something to life. It's almost like an inversion of that Pygmalion story. Life-casting is all about freezing a moment of real life in sculpture.

MS: And also strengthening? Given the sculptures are 'all about love', did making them strengthen your relationship with Jenny?

MQ: I think it's an amazing thing to have done something in art, because art lasts longer than life does. You know, with the classical, we're talking about sculptures from some two millennia ago, aren't we? Maybe these statues - or some of them will last 2000 years.

MS: I hope so!

MQ: And people will hopefully still be in love, hopefully the pieces will still speak to people.

MS: Let's see if humanity lasts that long! I'm not optimistic... In any case, the question of 'legacy' leads us to the museum where Drawn from Life is installed. ${ }^{18}$ You decided to set these pieces in the houses where Sir John Soane (1753-1837) installed his collection. Like Soane, you're a collector too, I think?

MQ: Yes. If you love art, if you love all art, it's a natural thing to do - once you can afford to have art around you. I find it inspiring to have works by other artists around.

\footnotetext{
${ }^{17}$ Ovid, Metamorphoses, X.243-97. For the centrality of touch within the passage - and in ancient sculpture at large - cf. V. J. Platt and M. J. Squire, 'Getting to Grips with Classical Art: Rethinking the Haptics of Graeco-Roman Visual Culture', in Touch and the Ancient Senses, ed. A. Purves, London, 2018, pp. 75-104. On the enduring power of the Pygmalion myth, see e.g., K. Gross, The Dream of the Moving Statue, Ithaca, NY, 1992; R. Jenkyns, Dignity and Decadence: Victorian Art and the Classical Inheritance, Cambridge, 1992, esp. pp. 115-42; J. Essake, Pygmalion and Galatea: The History of a Narrative in English Literature, Aldershot, 2001; V. I. Stoichita, The Pygmalion Effect. From Ovid to Hitchcock, Chicago, 2008; G. L. Hersey, Falling in Love with Statues: Artificial Humans from Pygmalion to the Present, Chicago, 2009, esp. pp. 90-131; J. Moshenska, Feeling Pleasures: The Sense of Touch in Renaissance England, Oxford, 2014, esp. pp. 92-100.

${ }^{18}$ For a brief guide to the museum, see T. Knox and D. Moore, The Sir John Soane's Museum, London, London, 2016 - with detailed further reading.
} 
MS: And how would you characterize your collection?

MQ: It's very, very diverse; I kind of buy what I like. Ancient. Modern. All the way, really.

MS: And if you could acquire any piece, from anywhere, what would it be?

MQ: I don't know. What would you say?

MS: I'm not sure. Probably something lost. Maybe the alleged line-painting by Protogenes and Apelles, do you know the story? Pliny the Elder calls it an absolutum opus (an 'absolute work' of art), even though it 'contains nothing on its vast surface' except for three 'almost invisible lines' - each of supreme artistic mastery, in different colours, and each finer than the last. ${ }^{19}$ We're told that it was destroyed in the first century $A D$ - but I find it rich it in the context of 'modern classicisms' - and of 'classical modernisms'....

MQ: That sounds really cool. I really don't know what mine would be. It's difficult because I like so many things, I can't really think of one thing....

MS: Is there at least a favourite classical sculpture?

MQ: Well again, I like so many different ones. It's very difficult to think of... Let me try and think of something that I really like... I love that life-size Hellenistic bronze boxer, the one in the recent Getty show... do you know the one I mean, from Rome ${ }^{20}$ But that's really just off the top of my head.

MS: Interesting, I can see why that would appeal. Well, Soane was not just a collector. In 1833, he also acquired an act of Parliament to turn his own home into a museum, so that his collection could be preserved just as it was. The museum is crowded with furniture, antiquities, models sculptures, and paintings - arranged as they were when Soane died in 1837. How do you think the museum colours an interpretation of your statues, and how do your works affect a view of the museum?

MQ: I think they are both complementary to each other. The backdrop of the museum underlines the classical aspect of these sculptures: when you show them in a white space, they look more - well, they might be less obviously classical, less about the art of the past (cf. e.g., Figs. 10, 11). What I like about the museum is its collection of fragments - of

\footnotetext{
19 Pliny, Natural History, XXXV.81-3 (spatiose nihil aliud continentem quam lineas uisum effugientes); for discussion and further bibliography, see M. J. Squire, 'Sémantique de l'échelle dans l'art et la poésie hellénistiques', in D'Alexandre à Auguste: dynamiques de la création dans les arts visuels et la poésie, ed. P. Linant de Bellefonds, É. Prioux and A. Rouveret, Rennes, 2016, pp. 183-200 (at pp. 183-4).

${ }^{20}$ Rome, Museo Nazionale Romano (Palazzo Massimo alle Terme): inv. 1055: cf. e.g., B. S. Ridgway, Hellenistic Sculpture III: The Styles of Ca. 100-31 B.C., Madison, WI, 2002, pp. 84-6. The statue was shown in the 2015 exhibition at the Getty Villa, Power and Pathos: Bronze Sculpture of the Hellenistic World.
} 
every kind, from architectural pieces to fragments of figurative sculpture. Soane's Museum is built from fragments. It's like some kind of three-dimensional google-search of history, but one that exists in reality. It's almost like being in someone's brain: the museum is a memory, a memory box - the world's cultural memory in a microcosm.

MS: And your pieces are the latest fragments to be added - temporarily - to the collection?

MQ: A fragment is like a moment, isn't it? And the museum is like a fragment from the past.

MS: Do you think that something's more beautiful when it's fragmented? Rodin is famously said to have declared that 'une belle chose en ruine est plus belle qu'une belle chose.' ${ }^{21}$

MQ: Well, I think there's certainly an element of that. A fragmented thing is something that's unknowable, and therefore ambiguous, something you can think about.

\section{MS: So the fragment lends itself to contemplation?}

MQ: It lends itself to dreaming, yes. You fill in the absences yourself.

MS: But in this case the dreams are also controlled. I'm thinking about the various juxtapositions in the museum - 'Gold' next to a bronze cast of the Medici Venus (with the same position of the hands [Fig. 13]), for example, 'Nature's' next to another naked Venus, or 'Hot' in the Monk's Parlour (its headless shape set against the fragmented sculpted heads that hand on the back wall [Fig. 1]). Were the juxtapositions intentional?

MQ: Yes, to some extent they were. But there could have been, what, twelve other completely different ones, and perhaps they would have been better. In any case, they'd be different. The relationship between 'Gold' and the Capitoline Venus was a very obvious juxtaposition to do. But I like 'Heaven' with the Belvedere Apollo - the two bums seen from the back (Fig. 14). And I like the two slightly 'Egyptian' statues in the front red room (Fig. 9), each in the window, with their arms crossed: it makes you think of the alabaster sarcophagus of King Seti downstairs (and those windows are almost like sarcophagi, aren't they?).

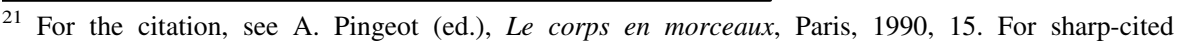
discussion, cf. O. Rossi Pinelli, 'The Fragment: Self-Sufficiency and "Responses" in the Restoration of Antiquities in the Nineteenth Century', Center (National Gallery of Art: Center for Advanced Studies in the Visual Arts), 20, 2000, pp. 148-51.
} 
MS: So the installation becomes part of the artwork - in good modernist tradition! ${ }^{22}$ Likewise, the fragments become 'interlocutors' with one another, as the Director of Sir John Soane's Museum has put it. ${ }^{23}$

MQ: Each room is very different and brings with it a different quality: you have to keep on looking to see what emerges.

MS: That idea of 'reflection' comes to the fore to in the literal reflections too - the multiple views of statues, seen for example in the convex mirrors that Soane installed (e.g., Figs. 7, 8). With that in mind, I wanted to ask about colour. Often, the use of stained glass changes the hue of these statues: with 'Hot' - set up in the Monk's Parlour (Fig. 1) - a yellow light is channeled through the hollow 'piping' of the legs. Likewise, those two 'Egyptian-'pose statues that you just mentioned radiate the glorious pink of the window blinds (Fig. 9). These variations in colour develop the polychromy of the statues themselves, with their greys, whiles, blues and blacks (sometimes combined in a single piece like 'Life' (Fig. 9, 10). What is colour doing here?

MQ: When statues are cast in fibreglass they take on different shades. A pretty palette emerges - of blue, grey, brown, beige, white, sometimes a bit of black. That palette of fibreglass is the palette that I've used, but it's also a bit like the palette of an egg shell.

MS: So not a response to the polychromy of ancient sculpture? ${ }^{24}$

MQ: I don't think it's about that: the pieces are referring to ancient sculpture, but in a kind of non-polychrome, handed-down way, even when we know this wasn't their historical appearance.

MS: When we think of the classical we tend to think of white, shining marble. Is there a challenge to that literal and metaphorical 'whiteness' here-even a question of 'race' (given that Jenny, your 'Muse', is black). As a classicist, the works instantly make me think about so-called 'Black Athena' debates....

MQ: Well, that's why there are lots of different colours. The colours aren't based on skin colour, or on different skin colours. It's an aesthetic that again appeals to the imagination.

\footnotetext{
22 The most famous example, of course, is Marchel Duchemp's Fountain (1917); among countless discussions, see e.g., A. C. Danto, The Abuse of Beauty: Aesthetics and the Concept of Art, Chicago, 2003, esp. pp. 9-11.

23 Cf. Marc Quinn: Drawn from Life (n. 1 above), p. 63.

24 Among numerous recent publications, cf. e.g., V. Brinkmann and R. Wünsche (ed.), Bunte Götter: Die Farbigkeit antiker Skulptur, Munich, 2004; cf. R. Panzanelli, E. D. Schmidt and K. Lapatin (ed.), The Color of Life: Polychromy in Sculpture from Antiquity to the Present, Los Angeles, 2008 and M. B. Abbe, 'Polychromy', in The Oxford Handbook of Roman Sculpture, ed. A. Friedland, M. G. Sobocinski and E. K. Gazda, Oxford, 2015, pp. 173-88 (with further bibliography).

25 M. Bernal, Black Athena: The Afroasiatic Roots of Classical Civilization, 3 vols, New Brunswick, NJ, 1987-2006. On the importance of Bernal's work, and for a range of responses, see D. Orrells, G. K. Bhambra and T. Roynon (ed.), African Athena: New Agendas, Oxford, 2011.
} 
MS: And what do you think Soane himself would have made of the installation?

MQ: I don't know. I hope he would have liked it. He might have said, 'I should have put more in there myself!' Or he might have thought, 'I didn't realize how under-hung the museum is!' - how much space there still was, that he could fit twelve more life-size statues in there.

MS: At this stage, let me zoom out a little. All About Love is just the latest in a series of continuing engagements with classical artistic traditions - statues like Self (a series initiated in 1991 [Fig. 1]), ${ }^{26}$ Emotional Detox (1993-1994), Complete Marbles (1999-2005 [e.g., Figs. 17, 18]), ${ }^{27}$ Alison Lapper Pregnant (2004 [Fig. 19]), ${ }^{28}$ Siren (2008 [Figs. 4, 5]), ${ }^{29}$ and Planet (2008). ${ }^{30}$ How do you think future critics might situate All About Love within your auvre?

MQ: I think, as you say, it's a continuation. There are technical differences too. The works in All About Love use the same life-casting technique as Emotional Detox, for example. But at that time I didn't yet have the silicone rubber, and so I used alginate for the cast instead - which is essentially powdered seaweed. All these pieces form part of a continuing investigation into the fragment - into ideas of wholeness, into different aspects of the classical.

\section{MS: So, once again, part of a larger rethinking about what the classical is?}

MQ: Yes. The sculptures of disabled people that I did - in Complete Marbles (cf. Figs. 17, 18), which ended up culminating in Alison Lapper (cf. Fig. 19) - those were statues about these ideas too. ${ }^{31}$ You see someone in a museum looking at the

\footnotetext{
${ }^{26}$ For the series - initiated in 1991, and sculpted every five years - see http://marcquinn.com/artworks/ self.

27 For a catalogue accompanying an exhibition of the work - at Mary Boone Gallery in New York - see Marc Quinn: The Complete Marbles, New York, 2004.

28 For a publication on the statue, see Marc Quinn: Fourth Plinth, Göttingen, 2006; cf. also above, n. 4. On the making of the statue, see http://marcquinn.com/studio/studio-diaries/the-making-of-alison-lapperpregnant. In 2012, as part of the opening ceremony of the Paralympic Games in London, Quinn created another version of the same subject - albeit in a very different medium, and this time over 12 metres in height: Breath used double-layer polyester and was designed to be quickly inflated - a 'cultural image of the sculpture literalised as an inflatable' (cf. http://marcquinn.com/artworks/single/breath).

29 For images - complete with an essay by Germaine Greer and an interview with the artist by Will Self - see Siren, London, 2008. Cf. also http://marcquinn.com/artworks/single/siren.

30 The colossal bronze statue was first displayed in Chatsworth House, but donated for permanent display at the Gardens by the Bay in Singapore in 2013: cf. dishttp://marcquinn.com/artworks/single/planet.

31 For the statues - made with traditional marble masons at Pietra Santa in Italy - see http://marcquinn. com/artworks/the-complete-marbles. The online catalogue explains how the statues, 'by adopting the language of idealism, ... relate to images of "idealized" beauty that Neoclassicism sought to represent.' But they are also said to 'highlight the fact that while the notion of an incomplete body is something that is celebrated and acceptable within the context of art history, it is not always so in real life': 'these works explore the contradictions between our outside appearance and inner being, celebrating imperfection and the beauty of different kinds of bodies as well as the strength and vitality of the human spirit.'
} 


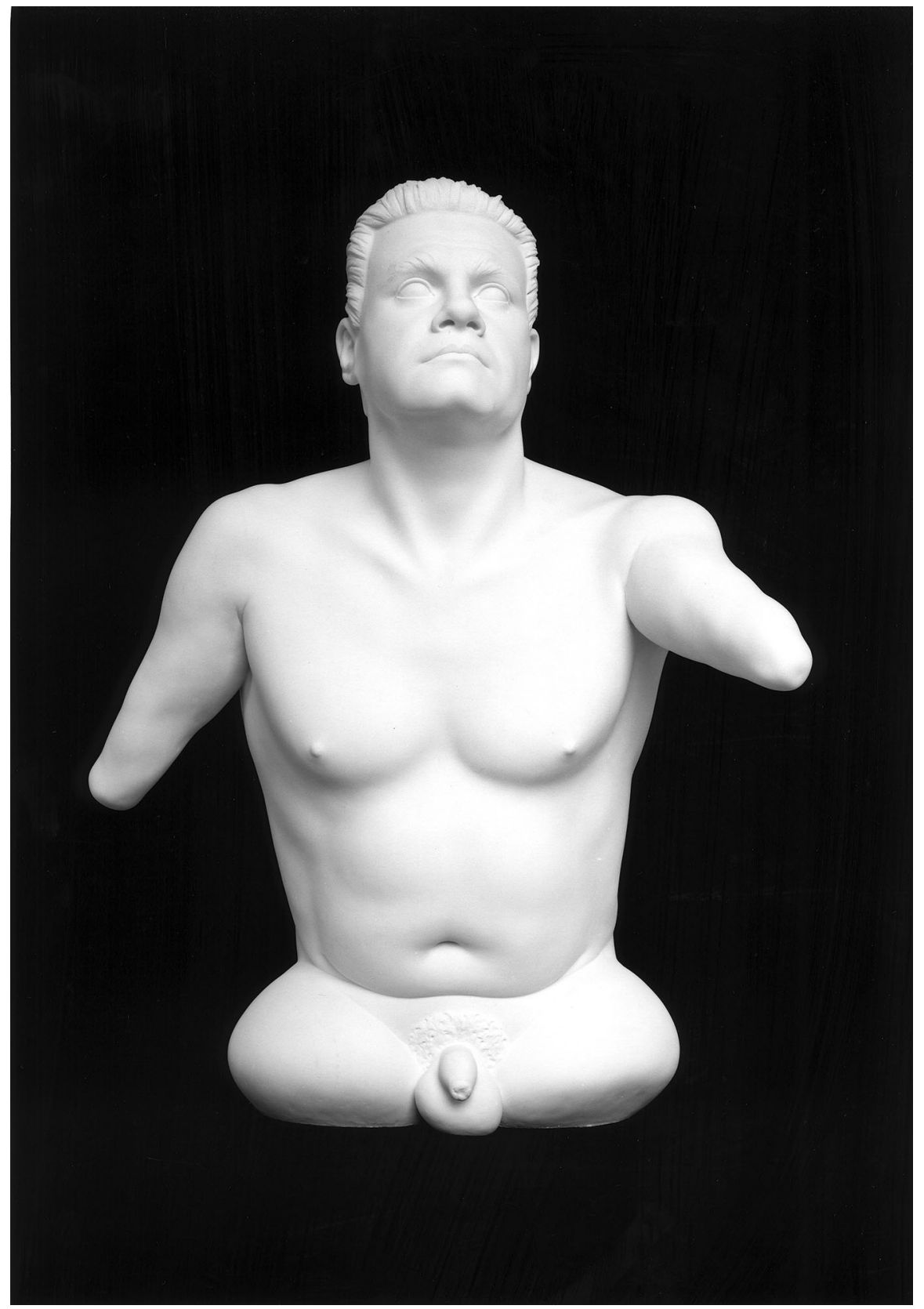

Fig. 17 Marc Quinn, The Complete Marbles 'James Gillespie' (1999). Marble; $180 \mathrm{~h} \times 51 \mathrm{~d}(\mathrm{~cm})$. Reproduced courtesy of Marc Quinn, (c) Marc Quinn studio 


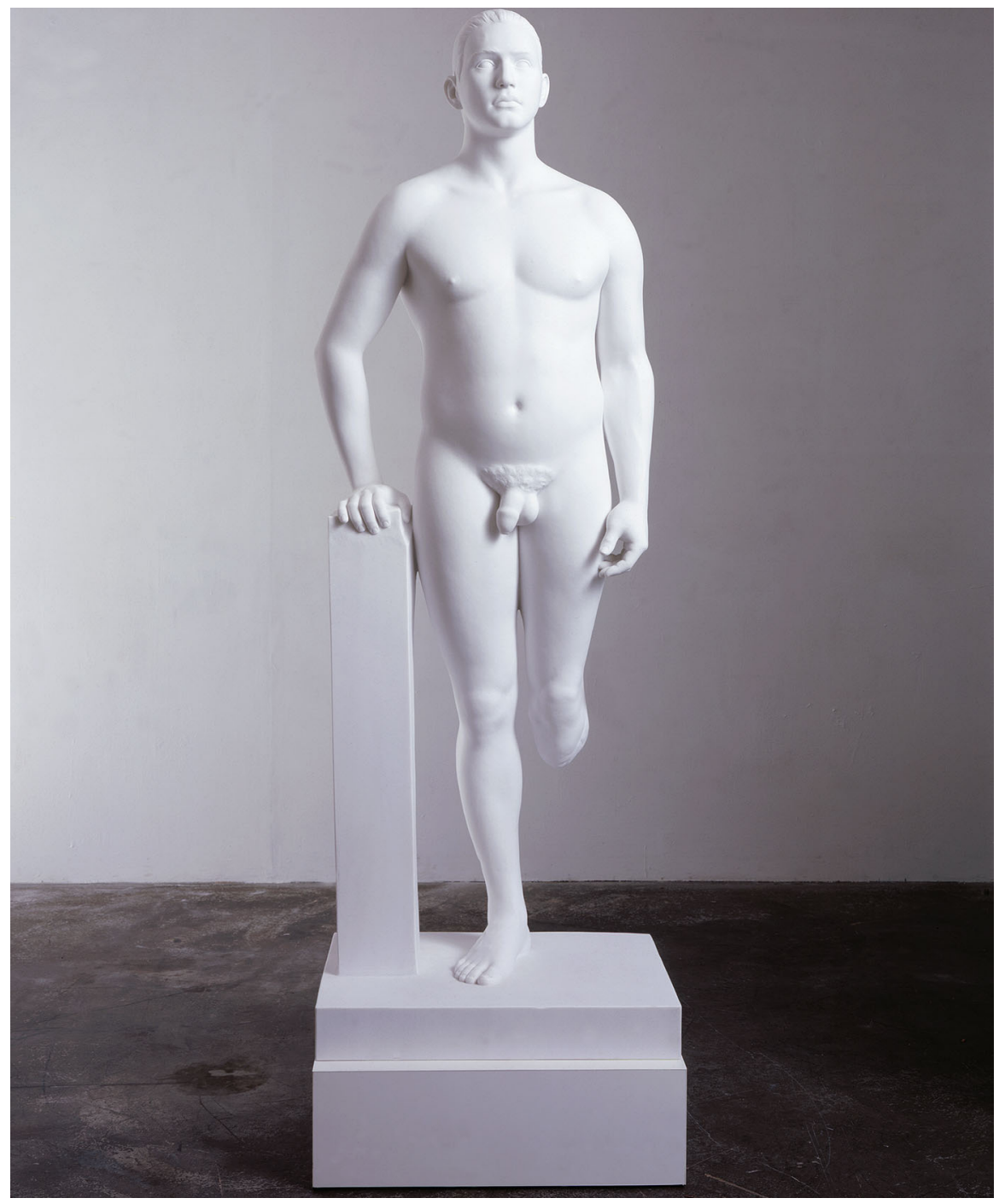

Fig. 18 Marc Quinn, The Complete Marbles 'Peter Hull' (1999). Marble; $84 \mathrm{~h} \times 66 \mathrm{w} \times 38 \mathrm{~d}(\mathrm{~cm})$. Reproduced courtesy of Marc Quinn, (C) Marc Quinn studio

'Venus de Milo' or the 'Elgin Marbles', and they say 'oh, this is one of the most beautiful sculptures of a human being ever made.' But when you have a real person of that shape in the room, people would likely react in a very different way; they're slightly uncomfortable, awkward even, unsure how to respond. It seemed really interesting to me that we accept something and celebrate it in art, but that we find it problematic in real life. 


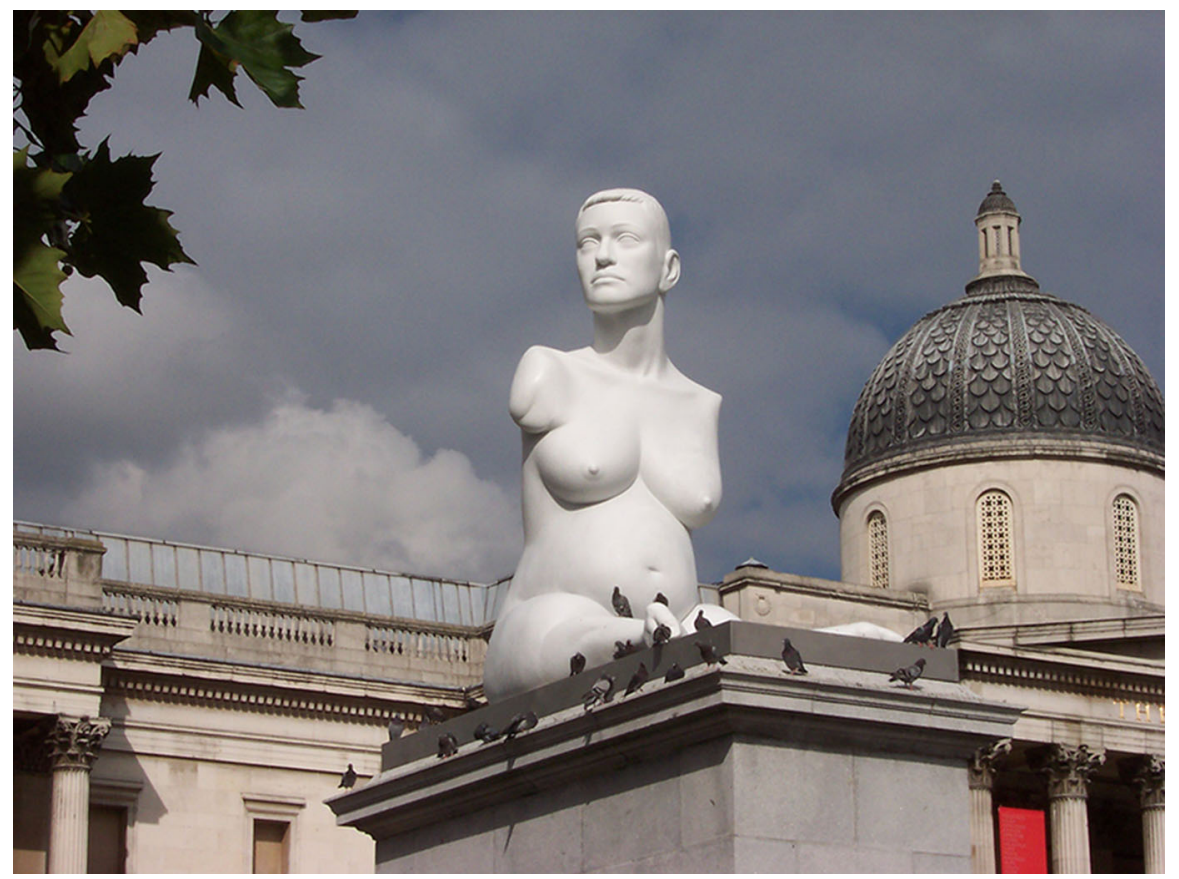

Fig. 19 Marc Quinn, Alison Lapper Pregnant (2004), as temporarily installed on the fourth plinth of Trafalgar Square in London. Marble; $355 \mathrm{~h} \times 180.5 \mathrm{w} \times 260 \mathrm{~d}(\mathrm{~cm})$. Reproduced courtesy of Marc Quinn, (C) Marc Quinn studio

MS: At once a celebration and a subversion, then, of classical associations?

MQ: I thought: well, why don't I find people who really do have body shapes like these sculptures and then make statues of them in marble and see what happens. So I made this basically neoclassical-style sculpture of Peter Hull, for instance who was born without legs and with shortened arms (Fig. 17); or a marble bust now in Mougins [Musée d'Art Classique de Mougins] - of Bill Walthier, who was blind from birth, in the style of an ancient Roman portrait. What you get is this strange result: traditionally, marble is the material of cultural celebration; but when you see a sculpture, a perfect sculpture, of someone with a disabled body it kind of makes you think they must come from a more enlightened culture in some way, a culture in which different kinds of beauty are celebrated. From taking an idea and medium from the past, I ended up with something that seemed very futuristic to me when I made them.

MS: As you say, you're also dealing there with a different material: marble. These latest pieces are made in fiberglass. Your Siren statue of Kate Moss was made from around 50 kilos of 18-carat gold (Figs. 4, 5), your series of Self portraits are made from ten frozen pints of your own blood (Fig. 3). 


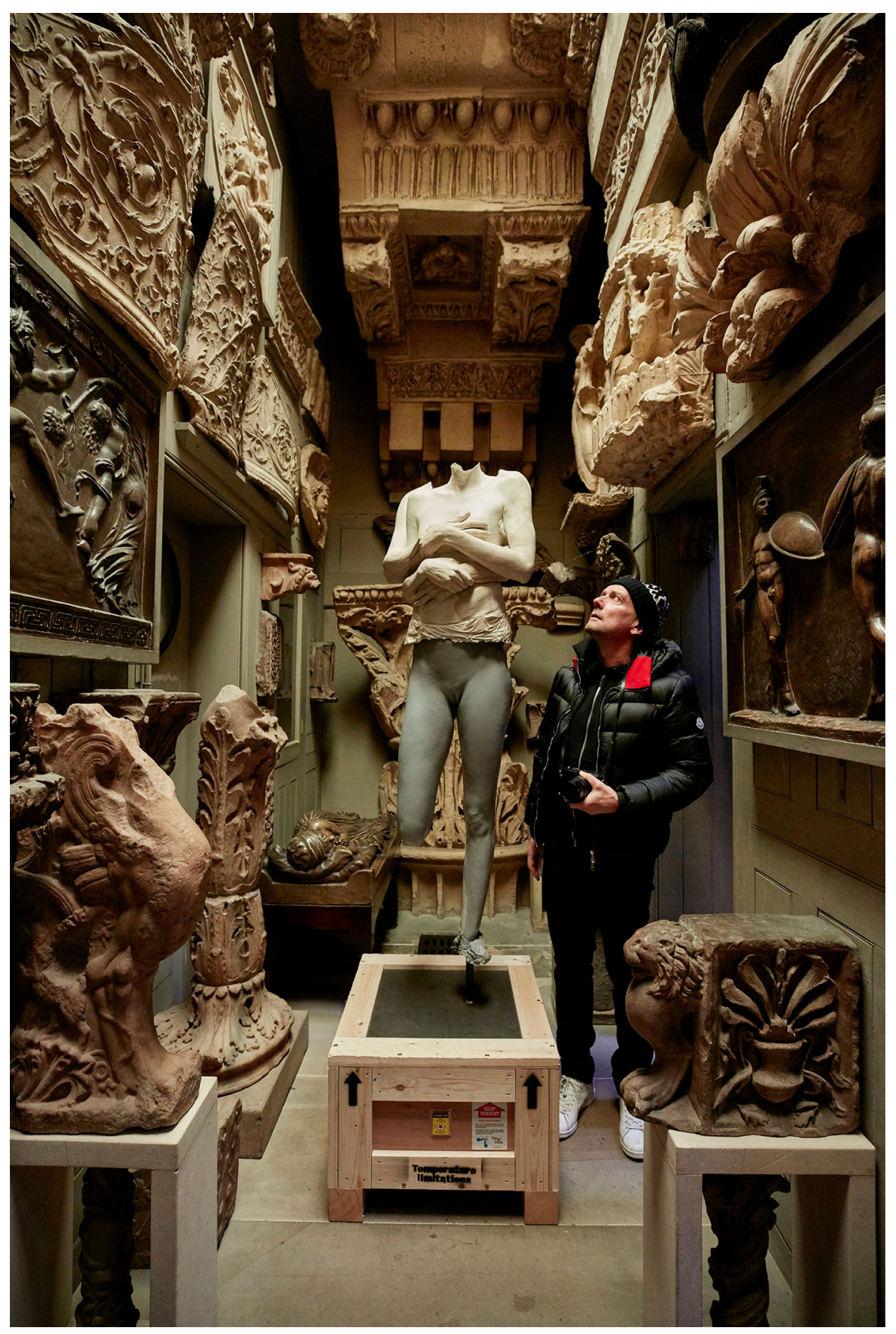

Fig. 20 Marc Quinn standing beside All About Love 'Untrimmed' (2016-2017) in Sir John Soane's Museum, March 2017 
MQ: I think it's always good to find a new material. And I just think for these pieces the fibreglass is - well, I am very happy with it.

MS: I want to end by returning us to the theme of 'classicism' with which we began. You have very kindly offered to participate in our 'Modern Classicisms' project, on contemporary artistic responses to ancient materials. How do you think contemporary artists help us to understand the art of the classical past?

MQ: That's a big question. First, I think all art was contemporary once: that's important to remember. But I'm not sure that you can give a blanket answer to a question like that. Maybe the contemporary can help us understand the classical maybe some of it can, maybe some of it can't. I think all art relates in different ways, and in different juxtapositions.

MS: What about All About Love - those juxtapositions in Sir John Soane's Museum (Fig. 20)?

MQ: Well, I think it is... I don't know, to be honest - lots of different things, everything that we've talked about. You have to look.

MS: In which case, let me close by giving one final sound-bite and see what you make of it. Pablo Picasso declared that 'The beauties of the Parthenon, Venuses, nymphs, Narcissuses, they're all so many lies; art is not the canon of beauty but what the instinct and brain can conceive beyond any canon - when we love a woman, we don't start measuring her limbs. ${ }^{32}$ What do you think is meant by that?

MQ: The whole point of art is to present you with something new - it shows you things that are beautiful that you wouldn't have anticipated, that you might not have thought possible. But then you don't have to submit into a system. Art is trying to give people what they didn't know they wanted. You don't give what people what they want. You give them what they didn't realise they desired.

$$
* * *
$$

Acknowledgements Various people have helped in the preparation of this article. First and foremost, it is a pleasure to thank Marc Quinn, for generously discussing his work and providing photographs. For their help in arranging the interview and answering questions, I am also grateful to Damian Simpson (Director of the Marc Quinn studio), Rachel John (Sutton), Sharis Alexandrian (Director of White Cube), Owen Hopkins (Senior Curator of Exhibitions and Education, Sir John Soane's Museum) and Bruce Boucher (Director, Sir John Soane's Museum). The final version of the article has benefitted from discussions with Daniel Orrells, and from comments by the journal's two anonymous readers. My research here forms part of a larger project on Modern Classicisms in the Department of Classics at King's College London (cf. www.modernclassicisms.com); the project is run in partnership with the Musée d'Art Classique de Mougins, and has been generously supported by Christian Levett.

\footnotetext{
32 Cf. M. J. Squire, The Art of the Classical Body, London, 2011, esp. 24-7 (with further reading at 208-09).
} 
Open Access This article is distributed under the terms of the Creative Commons Attribution 4.0 International License (http://creativecommons.org/licenses/by/4.0/), which permits unrestricted use, distribution, and reproduction in any medium, provided you give appropriate credit to the original author(s) and the source, provide a link to the Creative Commons license, and indicate if changes were made.

\section{Appendix: Exhibited Works by Marc Quinn}

\section{Solo Exhibitions (Selected)}

2017

'Drawn from Life': Sir John Soane's Museum, London

'Thames River Water': Ivorypress, Madrid

2016

'Traces of Life': Anima Gallery, Qatar

'Frozen Wave (The Conservation of Mass)': Museum of Islamic Art, Qatar

2015

'Frozen Waves, Broken Sublimes': Somerset House, London

'The Toxic Sublime': White Cube, London

'History Painting': BOX, Berlin

2014

'Violence and Serenity': Centro de Arte Contemporáneo (CAC), Málaga

'The Sleep of Reason': ARTER Space for Art, Istanbul

\section{3}

'Held by Desire': White Cube, Hong Kong

'Marc Quinn': Fondazione Giorgio Cini, San Giorgio, Venice

'The Rush of Nature': Chelsea Flower Show, London

'All the Time in the World': Mary Boone Gallery, New York

'Planet': Gardens by the Bay, Singapore (permanent installation)

2012

'Breath': London, 2012 Paralympics Opening Ceremony

'Marc Quinn': Museum of Modern Art, Aalborg

'Marc Quinn': Musée Océanographique de Monaco

‘Marc Quinn': Galerie Thaddaeus Ropac, Salzburg

'Big Wheel Keeps on Turning': Multimedia Art Museum, Moscow

2011

'All of Nature Flows Through Us': Kistefos Museum, Jevnaker, Norway (permanent installation) 
'Allanah, Buck, Catman, Chelsea, Michael, Pamela and Thomas': White Cube, London

'Marc Quinn': Patricia Low Contemporary, Gstaad

2009

'Iris': Mary Boone Gallery, New York

'Marc Quinn': Goss-Michael Foundation, Dallas

'Marc Quinn: Selfs': Fondation Beyeler, Basel

'Materialise, Dematerialise': Galerie Thaddaeus Ropac, Salzburg

'Carbon Cycle': Galerie Daniel Blau, Munich

'Il Mito': Casa Giuleta, Verona

2008

'Evolution': White Cube, London

'Before, Now and After': Galerie Hopkins-Custot, Paris

'Marc Quinn': Gana Art Gallery, Seoul

'Alison Lapper Pregnant': Roman Forum, Rome

2007

'Marc Quinn': DHC/ART Foundation for Contemporary Art, Montreal

'Marc Quinn': Parco Internazionale della Scultura, Museo MARCA, Catanzaro

'Sphinx': Mary Boone Gallery, New York

2006

'Paintings': Emanuele Bonomi, Milan

'Marc Quinn': Museo d'Arte Contemporanea (MACRO), Rome

'Recent Sculpture': Groninger Museum, Groningen

'Marc Quinn': Galerie Hopkins-Custot, Paris

'Chemical Life Support': Millesgarden, Stockholm

2005

'Marc Quinn': Galeria Guereta, Madrid

'Alison Lapper Pregnant': Fourth Plinth, Trafalgar Square, London

'Chemical Life Support': White Cube, London

'Flesh': Mary Boone Gallery, New York

2004

'The Incredible World of Desire': IBM Building, New York

'Marc Quinn': Atkinson Gallery, Millfield School, Somerset

'Flesh': Irish Museum of Modern Art, Dublin

'The Complete Marbles': Mary Boone Gallery, New York

2003

'The Overwhelming World of Desire (Phragmipedium sedenii)': Peggy Guggenheim Collection, Venice

'Mirror': Power House, Memphis 
'The Overwhelming World of Desire (Paphiopedilum Winston Churchill Hybrid)': Goodwood Sculpture Park, United Kingdom; Tate Britain, London

2002

'Behind the Mask - Portraits': Hatton Gallery, Newcastle

' $1+1=3$ (Rainbow Sculpture)': Cammell Laird Shipyard, Liverpool

'Marc Quinn': Tate Liverpool

2001

'A Genomic Portrait - Sir John Sulston by Marc Quinn': National Portrait Gallery, London

'Italian Landscape': Habitat, London

'Marc Quinn - Garden': Art of This Century, Paris

2000

'Still Life': White Cube, London

'Marc Quinn': Groninger Museum, Groningen

'Marc Quinn': Fondazione Prada, Milan

1999

'Marc Quinn': Kunstverein Hannover

'Marc Quinn - Drawings': Sala Amárica-Amarica Aretoa, Victoria

1998

'Incarnate': Gagosian Gallery, New York

'Marc Quinn': South London Gallery, London

1997

'Infra-Slim Spaces': Invisible Museum, SCCA, Kiev

1995

'The Blind Leading the Blind': White Cube, London

'Art Now - Emotional Detox - The Seven Deadly Sins': Tate Gallery, London

1994

'Marc Quinn': Art Hotel, Amsterdam

1993

'Marc Quinn': Galerie Jean Bernier, Athens

1991

'Out of Time': Grob Gallery, London

1990

'Bread Sculpture': Galerie Marquardt, Paris; Middendorf Gallery, Washington 
1988

'Bronze Sculpture': Otis Gallery, London

\section{Group Exhibitions (Selected)}

\section{7}

'Christian Dior, Couturier du Rêve': Musée des Arts Décoratifs, Paris

'Winckelmann: Modern Antiquity': Klassik Stiftung, Weimar

'Where we are and where we have been': Kallos Gallery, London

'Hyper Real': National Gallery of Australia, Canberra

\section{6}

'Identity Revised': The Warehouse, Dallas

'Dreaming with Stanley Kubrick': Somerset House, London

'The World Meets Here': Custot Gallery, Dubai

'On the Origin of Art': Museum of Old and New Art, Hobart

'Audacious': Denver Museum of Art, Colorado

\section{5}

'From Hockney to Holbein': The Würth Collection, Berlin

'Face of Britain': National Portrait Gallery, London

'Beyond Limits': Chatsworth House, Derbyshire

\section{4}

'Art Everywhere': 30,000 public sites across the UK

'Open Air': Yorkshire Sculpture Park, West Bretton

'Bad Thoughts': Stedelijk Museum, Amsterdam

'Selected Works from the YAGEO Foundation Collection': National Museum of Modern Art, Tokyo

'Leaping the Fence': Hestercombe House, Taunton

'East Wing Biennial Exhibition': Courtauld Institute, London

\section{3}

'Beyond Limits': Chatsworth House, Derbyshire

'Louis Vuitton Timeless Muses': Tokyo Station Hotel, Tokyo

\section{2}

FIAC 2012: Jardin des Tuilleries, Paris

'Marc Quinn \& Darren Almond': Patricia Low Contemporary, St Moritz

\section{1}

'Surreal versus Surrealism': Contemporary Art, IVAM, Valencia

'Nothing in the World but Youth': Turner Contemporary, Margate

'Penelope's Labour - Weaving words and Images': Fondazione Giorgio Cini, Venice 'Beyond Limits': Chatsworth House, Derbyshire 
2010

'The Visceral Body': Vancouver Art Gallery

'Crucible': Gloucester Cathedral

'Cream': Kiasma, Museum of Contemporary Art, Helsinki

'The Foundation of Art, Sculpture and its Base since Auguste Rodin': Arp Museum, Remagen

'Beyond Limits': Chatsworth House, Derbyshire

'Realismus: Das Abenteuer der Wirklichkeit': Kunsthalle Emden; Kuntshalle Rotterdam; Kunsthalle Hypo-Kulturstiftung, Munich

2009

'The World in the Body': Mori Art Museum, Tokyo

'A Tribute to Ron Warren': Mary Boone Gallery, New York

'Messiah': Modem Centre for Modern and Contemporary Arts, Debrecen

'No Visible Means of Escape': Norwich Castle Museum and Art Gallery

'Assembling Bodies - Art, Science and Imagination': Museum of Archaeology and Anthropology, University of Cambridge

'Fuentes - Non-European Influences on Contemporary Artists': Galerie Thaddaeus Ropac, Paris

'Innovations in the Third Dimension - Sculpture of Our Time': Bruce Museum, Greenwich (Connecticut)

2008

'Love': National Gallery, London

'Out of Shape - Stylistic Distortions of the Human Form in Art': The Frances Lehman Loeb Art Center, Poughkeepsie, New York

'Genesis - Die Kunst der Schopfung': Zentrum Paul Klee, Bern, Switzerland

'Statuephilia - Contemporary Sculptors at the British Museum': British Museum, London

'Beyond Limits': Chatsworth House, Derbyshire

'Nothing But Sculpture - Eighth International Sculpture Biennale': Carrara

'Open XI International Exhibition of Sculptures and Installations': Lido and San Servolo, Venice

'Sphinxx': Stuart Shave/Modern Art, London

'Beyond Limits': Chatsworth House, Derbyshire

2007

'Garden of Eden': Kunsthalle Emden

'Skin': The National Museum of Art, Osaka

'Six Feet Under': Deutsches Hygiene-Museum, Dresden

'The Naked Portrait': Scottish National Gallery, Edinburgh; Compton Verney, Warwick

'Timer 01 - Intimità': Triennale Bovisa, Milan

'Genesis - Life at the End of the Information Age': Centraal Museum, Utrecht 
'Passion for Art - 35th Anniversary of the Essl Collection': Essl Museum of Contemporary Art, Klosterneuburg

'Framed: The Art of the Portrait': Art Gallery of Hamilton, Ontario

2006

'Aftershock - Contemporary British Art 1990-2006': Guangdong Museum of Art, Guangzhou; Capital Museum, Beijing

'Six Feet Under - Autopsy of Our Relation to the Dead': Kunstmuseum Bern

'Diagnosis (Art) - Contemporary Art Reflecting Medicine': Kunstmuseum Ahlen and Museum im Kulturspeicher, Wurzburg

'Light': Winchester Cathedral

'Eretica': Museum Sant'Anna, Palermo

'EGOmania - Just When I Think I've Understood...': Galleria Civica, Modena

2005

'Imagine a World': Bargehouse, London

'Wunderkammer - The Artificial Kingdom': The Collection, Lincoln

'Art Out of Place': Norwich Castle Museum and Art Gallery

'Ripe for Picking Fruits and Flowers': Jim Kempner Fine Art, New York

“"Bock mit Inhalt” (Summer Exhibition)': Stedelijk Museum, Amsterdam

'Summer Exhibition 2005': Royal Academy of Arts, London

'London Calling - Y[oung] B[ritish] A[rtists] Criss-Crossed': Galleri Kaare

Berntsen, Oslo

'Blumenstück - Künstlers Glück': Museum Morsbroich, Leverkusen

'The Body - Art \& Science': National Museum, Stockholm

'Contemporary Photography and the Garden - Deceits \& Fantasies': The Middlebury College Museum of Art, Vermont; The Parrish Art Museum, New York; Columbia Museum of Art; Tacoma Art Museum, Washington

2004

'Slimvolume 2004': Redux, London

'The Flower as Image - From Monet to Jeff Koons': Louisiana Museum, Humlebæk

'The Synaesthetics of Art and Public': Gwangju Biennale (South Korea)

'Lille Expo': Lille

'Garden of Eden': Helsinki City Art Museum

'The Garden of Delights': Galería Guereta, Madrid

'Flowers Observed, Flowers Transformed': The Warhol Museum, Pittsburgh

'Art of the Garden': Tate Britain, London; Ulster Museum, Belfast; Manchester Art Gallery

'Secrets of the 90s': Museum voor Moderne Kunst, Arnhem

'Flowers': Mary Boone Gallery, New York

'Ideale e Realtà': Galleria d'Arte Moderna, Bologna

2003

'Fourth Plinth Proposal': National Gallery, London

'Fresh - Contemporary British Artists in Print': Edinburgh Printmakers 
'Statements 7': Venice Biennale

'Decembristerne': Gallery Faurschou, Copenhagen

'Independence': South London Gallery, London

'Genomic Issues': Graduate Center Art Gallery, New York

'Bull's Eye - Works from the Astrup Fearnley Collection': Arken Museum of Modern Art, Ishøj

'UnNaturally': Contemporary Art Museum, University of South Florida, Tampa; H \& R Block Artspace at the Kansas City Art Institute; Fisher Gallery, University of Southern California, Los Angeles; Copia: The American Center for Wine, Food and the Arts, Napa; Lowe Art Museum, University of Miami

2002

'Face Off': Kettle's Yard, Cambridge

'The Nude in Twentieth-Century Art': Kunsthalle in Emden

'Rapture - Art's Seduction by Fashion Since 1970': Barbican Gallery, London

'Thinking Big - Concepts for Twenty-first Century British Sculpture': Peggy Guggenheim Collection, Venice

'The Rowan Collection - Contemporary British and Irish Art': Irish Museum of Modern Art, Dublin

'Life is Beautiful': Laing Art Gallery, Newcastle

'In the Freud Museum': Freud Museum, London

'Iconoclash - Beyond the Image Wars in Science, Religion and Art': ZKM Center for Art and Media, Karlsruhe

'Second Skin - Historical Life Casting and Contemporary Sculpture': Henry Moore Institute, Leeds

2001

'Sacred and Profane': Mappin Gallery, Sheffield

'Printers Inc.': The Gallery, Stratford-upon-Avon; The Royal Academy of Arts Charles Wollaston Award, London

'Summer Exhibition 2001': Royal Academy of Arts, London

'Ohne Zögern': Weserburg Museum of Modern Art, Bremen

'Metamorphosis and Cloning': Foundation for Contemporary Art, Montreal

'/Arts': The Lux, London

'London Nomad': Beit Zeinab Khatoun, Cairo Biennale

'Mind the Gap': Wetterling Gallery, Stockholm

'Give \& Take': Victoria and Albert Museum, London

'Heads and Hands': Decatur House Museum, Washington

2000

'Contemporary Art Trail': Wellcome Wing, The Science Museum, London

'Spectacular Bodies - The Art and Science of the Human Body from Leonardo to

Now': Hayward Gallery, London

'Conversation': Milton Keynes Gallery

'Out There': White Cube, London

'Psycho': Anne Faggionato, London 
1999

'Skin': Deste Foundation, Centre for Contemporary Art, Athens

'Something Warm and Fuzzy': Des Moines Art Center, Iowa

'Into the Light - Photographic Printing out of the Darkroom': The Royal Photographic Society, Bath

'Officina Europa': Galleria d'Arte Moderna, Bologna

'Now It's My Turn to Scream - Works by Contemporary British Artists from the Logan Collection': Haines Gallery, San Francisco

'Presence': Tate Liverpool

'Spaced Out - Late 1990s Works from the Vicki and Kent Logan Collection': The CCA Wattis Institute for Contemporary Arts, San Francisco

'As Above, So Below - The Body's Equal Parts': Fabric Workshop, Philadelphia 'Physical Evidence': Kettle's Yard, Cambridge

1998

'Family': Inverleith House, Royal Botanic Garden, Edinburgh

'Group Exhibition': Galleri Faurschou, Copenhagen

'Hope (Sufferance)': Sun and Doves Gallery, London

'The Colony Room 50th Anniversary Art Exhibition': A22 Projects, London

'A Portrait of Our Times - An Introduction to the Logan Collection': San Francisco Museum of Modern Art

'UK Maximum Diversity': Galerie Krinzinger, Benger Fabrik Bregenz

'Sam Taylor-Wood, Tracey Emin, Gillian Wearing and Marc Quinn': Galerija Dante Marino Cettina, Umag, Cettina

'Inner Self': Mitchell-Innes \& Nash, New York

1997

'The Quick and the Dead - Artists and Anatomy': Royal College of Art, London; Mead Gallery, University of Warwick; City Art Gallery, Leeds

'Sensation': Royal Academy of Arts, London; Hamburger Bahnhof, Berlin; Brooklyn Museum of Art, New York

'The Body': The Art Gallery of New South Wales, Sydney

'Follow Me': Kunstverein Kehdingen, Freiburg

'A Ilha do Tesouro': Fundaçao Calouste Gulbenkian, Lisbon

1996

'Thinking Print - Books to Billboards 1980-95': Museum of Modern Art, New York

'Hybrid': De Appel, Amsterdam

'Mäßig und gefräßig - Künstlerinstallationen': Museum für Angewandte Kunst, Vienna

'Works on Paper': Irish Museum of Modern Art, Dublin

'Happy End': Kunsthalle, Düsseldorf

1995

‘Time Machine': Museo Egizio, Turin 
'Faith, Hope, Charity': Kunsthalle, Vienna

'Contemporary British Art in Print': Scottish Museum of Modern Art, Edinburgh

'Ripple Across the Water': Minato Prefecture and Shibuya Prefecture, Tokyo

1994

'Life Is Too Much': Galerie des Archives, Paris

'Time Machine': British Museum, London

1993

'Prospect 93': Frankfurter Kunstverein and Schirn Kunsthalle, Frankfurt

'Sonsbeek 93': Arnhem

'Young British Artists from the Saatchi Collection': Art Cologne

'Real Real': Vienna Secession

'Restaurant': Galerie Marc Jancou, Paris

'Young British Artists II': Saatchi Collection, London

1992

'The Boundary Rider (Ninth Sydney Biennale)': Art Gallery of New South Wales, Sydney

'London Portfolio': Karsten Schubert, London

'Strange Developments': Anthony d'Offay, London

'British Art': Barbara Gladstone Gallery, New York

1991

'Modern Masters': Grob Gallery, London

1990

'Group Show': Grob Gallery, London

'Hands': Grob Gallery, London

Michael Squire is Reader in Classical Art at King's College London; he has held fellowships at Cambridge, Cologne, Harvard, Munich and Stanford, as well as at the Max-Planck-Institut für Wissenschaftsgeschichte and at the Wissenschaftskolleg zu Berlin. He has published widely on classical art and its reception - including books on The Art of the Body: Antiquity and its Legacy (2011), The Frame in Classical Art: A Cultural History (co-edited with Verity Platt, 2017), Rethinking Lessing's Laocoon: Antiquity, Enlightenment, and the 'Limits' of Painting and Poetry (co-edited with Avi Lifschitz, 2018), and The Art of Hegel's Aesthetics: Hegelian Philosophy and the Perspectives of Art Hisory (coedited with Paul Kottman, 2018). He is currently working on a project called 'Modern Classicisms: Classical Art and Contemporary Artists in Dialogue' at King's College London, with an associated exhibition at Bush House and Somerset House in spring 2018. 